\title{
Remarks on elements of Japanese landscape and their geotouristic attractiveness
}

\author{
Uwagi na temat elementów japońskiego krajobrazu i ich atrakcyjności geoturystycznej \\ Urszula Myga-Piątek \\ University of Silesia, Faculty of Earth Sciences, Department Regional Geography and Tourism \\ ul. Będzińska 60, 41-200 Sosnowiec; \\ e-mail: urszula.myga-piatek@us.edu.pl
}
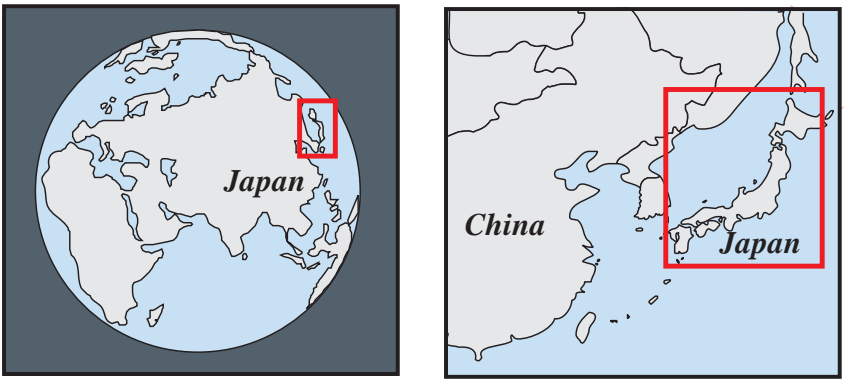

Abstract: For western tourists Japan is a mysterious country. That mystery was further increased by relatively long-lasting political isolationism, which consequently resulted in tourism isolationism. With tragic events - a 9-magnitude earthquake and a resulting gigantic tsunami, reaching 10 meters in height (11.03.2011) in the background, the author will analyze the geotourist potential of Japan. It can be predicted that, paradoxically, the strong earthquake and tsunami will soon result in an increased inflow of tourists. That might be related to the development of many new forms of geotourism, among which dark tourism became most and most popular.

In this highly urbanized country, the geological heritage creates relict landscapes which could be referred to as quasi-natural. There are very interesting from a tourist point of view. The article was based on the author's own observations during her study trip around Japan in May, 2009. The journey around picturesque and to a great extent wild, as for Japan, spots of Shikoku and Honshu, inspired the author to present a few notes regarding the geotourist attractiveness of that country. This is an attempt to assess the environmental potential from the point of view of an European tourist.

Key words: geotourism, Japan, volcanism, tsunami, tourism potential

Treść: Dla zachodnich turystów Japonia jest bardzo tajemniczym krajem. Tajemniczość ta wynika z dtugotrwałego izolacjonizmu politycznego, pociagajacego za soba zjawisko izolacjonizmu turystycznego. Artykuł analizuje potencjał geoturystyczny Japonii na tle tragicznych $w$ skutkach wydarzeń z 11 marca 2011 r. trzęsienia ziemi o magnitudzie 9 i fali tsunami o wysokości $10 \mathrm{~m}$. Można przypuszczać, że paradoksalnie silne trzęsienie i tsunami spowoduje w krótkim czasie zwiększony napływ turystów. Może to być skutkiem rozwoju wielu odmian geoturystyki oraz rosnacej popularności tzw. dark tourism.
W wysoko zurbanizowanym kraju dziedzictwo geologiczne tworzy reliktowe krajobrazy o stosunkowo wysokim stopniu naturalności. Moga one być bardzo atrakcyjne dla turystów. Artykut powstat na bazie obserwacji poczynionych podczas objazdu Japonii w maju 2009 r. Podróż przez malownicze $i$ w dużym stopniu dziewicze jak na Japonię miejsca na Honsiu i Sikoku zainspirowaty autorke do przedstawienia kilku uwag o atrakcyjności geoturystycznej Japonii. Jest to jednocześnie próba oceny potencjału środowiskowego Japonii z punktu widzenia europejskiego turysty.

Stowa kluczowe: geoturystyka, Japonia, wulkanizm, tsunami, potencjat turystyczny

\section{Introduction}

Until recently, Japan (Fig. 1) was an mysterious country to western man (Dziewanowski, 1975). That mystery was further increased by a relatively long-lasting political isolationism, which consequently resulted in tourism isolationism. Apart from congress or business trips, Japan was seldom in the center of attention of European or American tourists.

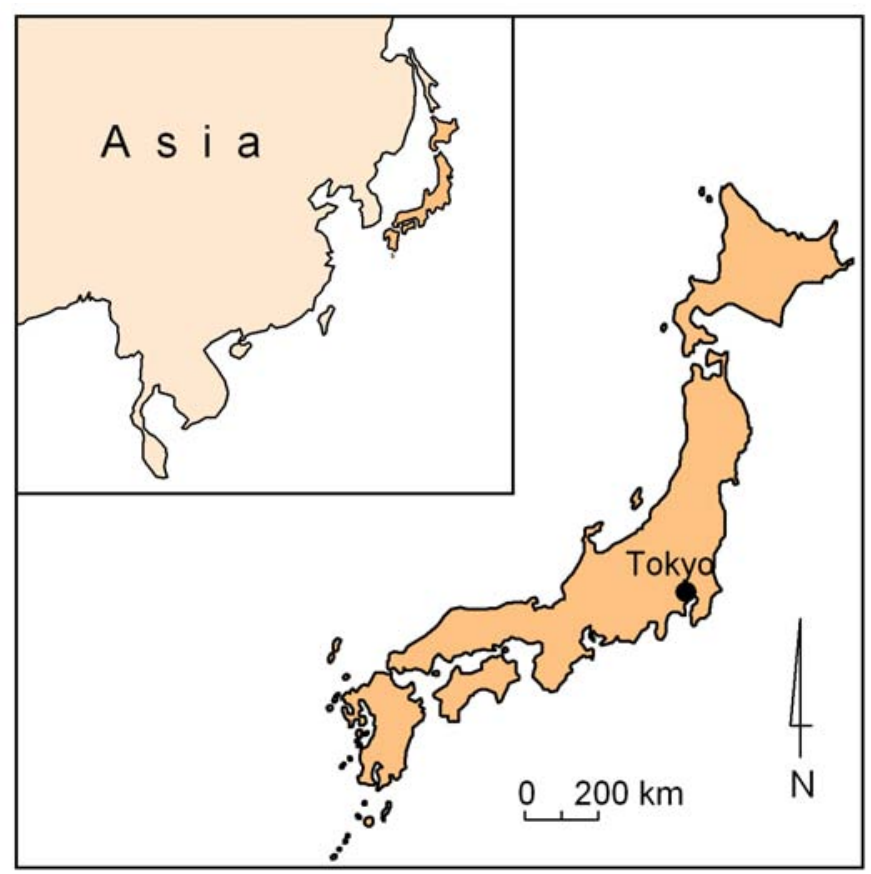

Fig. 1. Localization sketch area of Japan • Szkic lokalizacyjny Japonii 
At the same time, the Japanese are among the most active travelers in the world. In 2007, 17.3 million Japanese people left their home islands for tourist reasons, and the number has been growing steadily since then (Balaz, 1998). In the eye of a western tourist, the country is perceived through a number of very clear symbols and associations (see Myga-Piątek, 2010, 2011). Starting from March 11, 2011, the world will mainly associate Japan with the largest natural and nuclear disaster that occurred in a highly urbanized region. A 9-magnitude earthquake and a resulting gigantic tsunami, reaching 10 meters in height, devastated the Japanese islands. Locations that suffered most were those in prefectures of Miyagi (capitol prefecture is Sendai) and Iwate in the north-central part of the Honshu island (Fig. 2). The disaster had its geological consequences - the Honshu island was moved by over $2.4 \mathrm{~m}$ and the Earth axis shifted by $10 \mathrm{~cm}$. The earthquake damaged and caused an explosion of a reactor at the Fukushima 1 nuclear plant, and the leakage of radioactive substances and radioactively polluted water caused dramatic contamination of the islands and sea waters surrounding Japan (http:// wiadomosci.gazeta.pl/Wiadomosci/ as of 5.04.2011). The earthquake in Japan had its indirect effects on the global market and affected the world's economic activities through global corporate relations of Japanese companies. Minister of Defense Toshimi Kitazawa referred to the action of removing the effects of the earthquake and the tsunami as the largest logistic operation in the history of Japan.

With those tragic events in the background, the author will analyze the geotourist potential of Japan. It can be predicted that, paradoxically, the strong earthquake and tsunami will soon result in an increased inflow of tourists. That might be related to development of many new forms of tourism, including dark tourism.

The aim of this article is to assess the geotourist attractiveness of Japan. In this highly urbanized country, the geological heritage creates relict landscapes which could be referred to as quasi-natural. Geotourism will be referred to as a sector of sightseeing tourism, defined in its broadest meaning by A. Beaver (2005, p. 170) as: Geotourism - alternative for ecotourism. Tourism that sustains or enhances the geographical character of the places being visited, such as the environment, culture, aesthetic, heritage and the well-being of the residences. The basic definitions and terms have been written also by Słomka and Kicińska-Świderska, (2004) in Geotoursim.

This article was created based on the author's own observations during her study trip around Japan in May, 2009, being part of the research project titled: Comparative studies of protection and management of historical cities of Kyoto, Kanazawa, Krakow and Warsaw. The journey around picturesque and, to a high extent pristine, as for Japan, spots of Shikoku and Honshu, inspired the author to present a few notes regarding the tourist attractiveness of that country. This will also be an attempt to assess the environmental potential from the point of view of an European tourist.

Primary features of the Japanese landscape include high contrasts and large dynamics of the natural environment (Mydel, Groch, 2000). They result from the following characteristics of the natural environment:
- insular nature of the country;

- diverse and still very active tectonic-related (earthquakes, volcanic eruptions, tsunamis) and morphogenetic processes (including karst, denudation, nival and glacial processes, shore processes);

- high hypsometric differences - elevation differences between peaks (max. 3777 m. a.s.1.) and valley bottoms (500-200 m. a.s.1.) or cryptodepressions (down to $4 \mathrm{~m}$ b.s.1.) - may reach up to $2000 \mathrm{~m}$;

- occurrence of many lithostratigraphic types of rocks from flysch to crystalline, volcanic and carbonate rocks;

- well-developed river network and occurrence of underground flows in the zones of active volcanism - numerous hot springs;

- mosaics of the landscape resulting from lithological, morphological, soil and vegetation contrasts, which determine high picturesqueness;

- mountainous landscapes with clear altitudinal zonation of vegetation, occurrence of a number of relict and endemic species;

- very dynamic meteorological phenomena (typhoons, seas of fog, precipitation, long-lying snow cover in the north, temperature inversions).

\section{The outline of the environmental conditions in Japan}

Japan is located on 3,922 islands (from Jackowski, 1996), or, according to other sources, on as many as 6,852 (e.g. http:// en.wikipedia.org/wiki/Japan). The Japanese Islands are the caps of the massive mountain range rising 12,000 $\mathrm{m}$ above the sea bottom. The four largest ones - Honshu (most densely populated), Shikoku, Hokkaido and Kyushu - account for 98\% of the country's area (Fig. 1; Jackowski, 1996; Gudowski, Lisowski, 1997; Rutherford, 2006).

There still is a political dispute with Russia over four southern islands of the Kuril Archipelago: Iturup, Kunashir, Shikotan and Habomai (Weitz, 2011). The islands are characterized by diversified shoreline with numerous bays cutting deep into the land. Other islands are those of the Ryukyu Archipelago with the largest Okinawa, Bonin Islands, Izu Islands, Volcano Islands, Parece Vela, Marcus Island and Tsushima Island (Fig. 2). Over 3 thousand islands are uninhabited, hence, features of natural landscapes have been preserved there. The Japanese Islands stretch longitudinally for as much as $3,800 \mathrm{~km}$, which results in high diversification in terms of climate, vegetation and soil. Not only are the islands situated within the seismically active orogenetic zone (Fig. 2), but they are also located on the boundary of four tectonic plates: the Eurasian plate, the North American plate, the Pacific plate - moving westward (about $10 \mathrm{~cm}$ per year), and the smaller Philippine Sea plate. Subduction zones of the Pacific plate and the Philippine Sea plate under the Eurasian plate are delimited by the trenches: the Japanese Trench (8472 m b.s.1.), the Izu-Bonin Trench (9810 m b.s.1.) and the Ryukyu Trench (7861 m b.s.1.). 


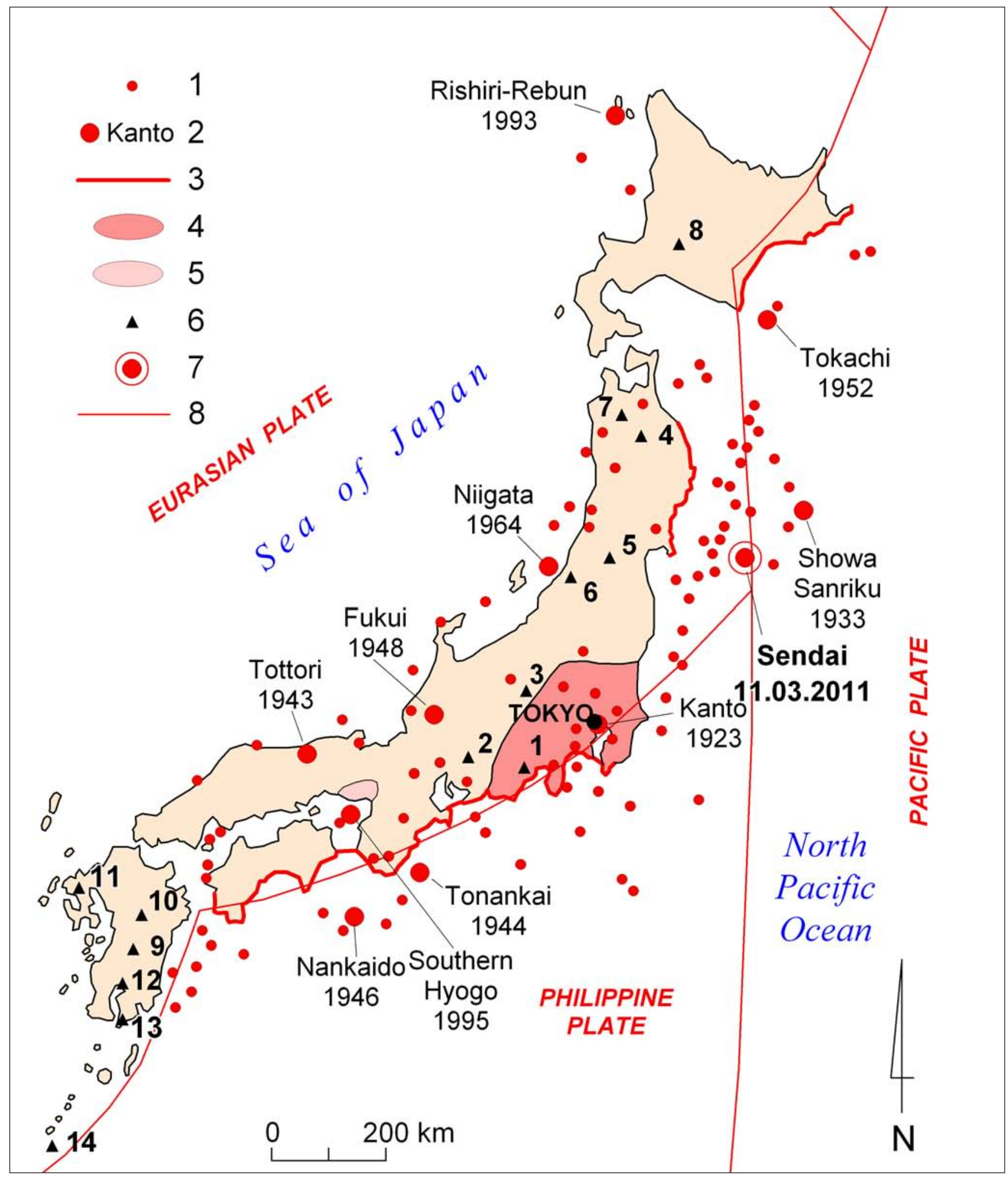

Fig. 2. Distribution of strong earthquake epicentre and main volcanoes in Japanese islands $(1-$ destructive earthquake epicentre $>$ 7-magnitude; 2 - the most disastrous sites; 3 - coasts threatened with waves tsunami; 4 - reach of a historic earthquake, Kanto, 1923); 5 - reach of a historic earthquake Hyogo, 1995; 6 - active volcanoes in the 20th century, number according to table 1; 7 - earthquake epicentre Sendai, 11.03.2011; 8 - main contact lines between lithosphere plates; lines of strong tectonic activity (compilation on the bases of Bornhof 2004; Gudowski, Lisowski 1997; Mydel, Groch, 2000) • Rozkład silnych trzęsień ziemi oraz lokalizacja największych wulkanów Japonii (1 - epicentra niszczących trzęsień ziemi o magnitudzie większej niż 7; 2 - najbardziej zniszczone obszary; 3 - wybrzeża zagrożone falami tsunami; 4 - zasięg historycznego trzęsienia w Kanto z 1923 roku; 5 - zasięg historycznego trzęsienia w Hyogo; 6 aktywne w XX w. wulkany - numeracja nawiązuje do wykazu w tabeli 1; 7 - trzęsienia w Sendai w dniu 11 marca 2011 roku; 8 -główne linie kontaktu płyt litosferycznych - strefy największej aktywności tektonicznej (opracowanie na podstawie Bornhof 2004; Gudowski, Lisowski 1997; Mydel, Groch, 2000) 


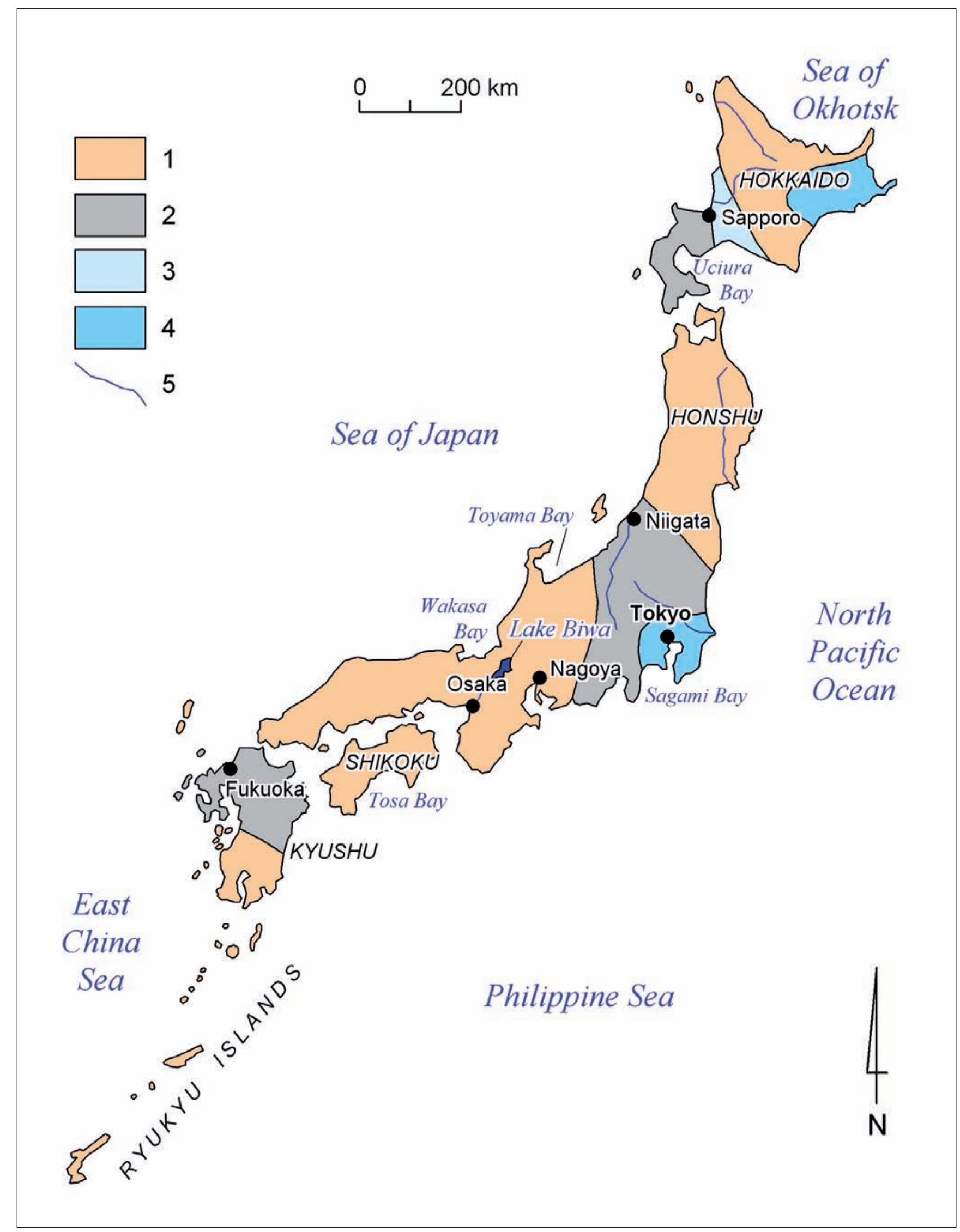

Fig. 3. Types of relief: 1 - low and middle mountains with horst relief; 2 - young volcanism areas; 3 - lowland of the rivers accumulation; 4 - lowland of the sea accumulation; 5 - main rivers (compilation on the bases of Bornhof 2004; Gudowski, Lisowski 1997; Mydel, Groch, 2000) • Typy rzeźby: 1 - niskie i średnie góry o rzeźbie zrębowej; 2 - obszary młodego wulkanizmu; 3 - niziny akumulacji rzecznej; 4 niziny akumulacji morskiej; 5 - główne rzeki (opracowanie na podstawie Bornhof 2004; Gudowski, Lisowski 1997; Mydel, Groch, 2000) 
The complex geological structure of the islands results from Paleozoic, Mesozoic and Alpine orogenetic movements. The main axis of the mountains was developed in the Mesozoic. Relief rejuvenation occurred during the Alpine orogenesis, when numerous fissures appeared and large vertical and horizontal movements took place. Tectonic movements accompanying the foldings resulted in many dislocations, volcanism (with lava flows and tufa sheets) and granite intrusions (Fig. 3).

The geological structure and surface features of the Japanese islands are also shaped by continuous volcanic processes, which affect the present landscape of the archipelago (Uhira et.al., 2004; Minakami, 1964; Tsuya, Morimoto, 1963; Geshi et.al., 2002). The territory of the country comprises almost 260 volcanoes, including between 40 and 80 volcanoes which show continuous activity (Tab. 1). The most famous is the Fuji-san volcano (Machida, 2002; Koyama, 1998; Ukawa, 2005). The number of volcanoes in Japan differs depending on the source. A. Jackowski (1996: 165), reports 265, whereas the Encyclopedia of Geography (Gudowski, Lisowski, 1997: 351) reports 160, including 40 active volcanoes. The most active ones (eruption in the past 120 years) are listed in Table 1.

Japan is subject to seismic shocks (1,000-3,000 per year) differing in magnitude. Some of the earthquakes, exceeding 7-magnitude on the Richter scale, become disasters (Fig. 2), like the great earthquake on the Kantō Plain in 1923 (143,000 victims) or Kobe in 1995 (6,000 victims). The Kantō Plain is particularly prone to earthquakes, which appear there every 70 years. Further threat comes from tsunami waves, which may reach $35 \mathrm{~m}$ in height (Bernacka, Piekarska-Gołębiowska, 1996), which is what the Japanese experienced on March 11, 2011. The extreme cases of tsunamis were those which destroyed the islands of Kamakura in 1495 or Okushiri in 1993. The tsunami of March 11, 2011, recorded and observed through mass media all over the world, was the largest natural disaster that has affected Japan in its history.

Thermal springs are related to the active volcanism zone. The area of Japan includes about 15,000 mineral springs, mostly thermal ones (mainly geysers), out of the total of 20,000 springs of waters with healing qualities. Geysers are particularly clustered on Kyushu and Hokkaido, but they can be regarded as a characteristic element of all Japanese islands.

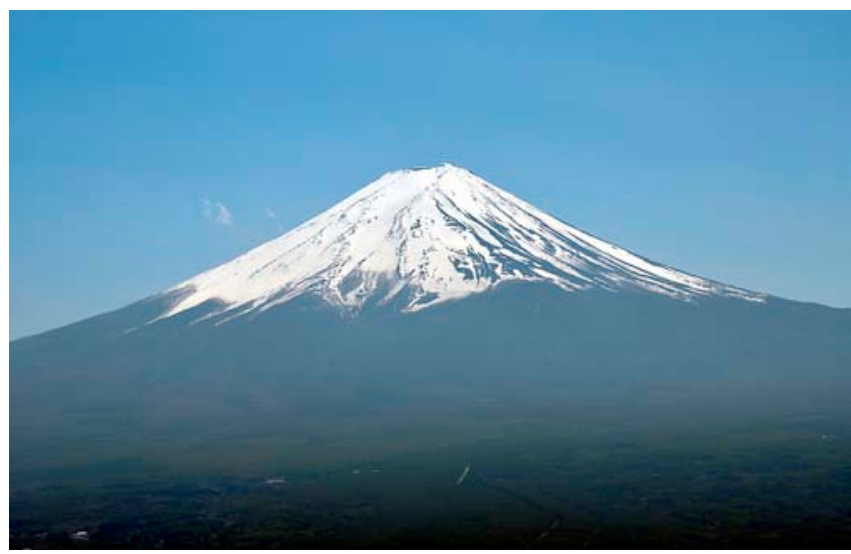

Fig. 4. Fuji san - the Japanese symbol and the holy mountain phot. J. Czakański • Fudżi - święta góra Japonii i symbol tego kraju, fot. J. Czakański

\begin{tabular}{|c|c|c|c|c|}
\hline $\begin{array}{l}\text { Number } \\
\text { Numer }\end{array}$ & $\begin{array}{l}\text { Name of volcano } \\
\text { Nazwa wulkanu }\end{array}$ & $\begin{array}{l}\text { Island } \\
\text { Wyspa }\end{array}$ & $\begin{array}{l}\text { High [m a.s.l] } \\
\text { Wysokośc [m n.p.m] }\end{array}$ & $\begin{array}{l}\text { Last eruption } \\
\text { Ostatnia erupcja }\end{array}$ \\
\hline 1 & Fudżi-san & Honsiu & 3776 & 1707 \\
\hline 2 & Ontake & Honsiu & 3067 & 1979 \\
\hline 3 & Asama-yama & Honsiu & 2542 & 1990 \\
\hline 4 & Iwate & Honsiu & 2041 & 1998 \\
\hline 5 & Azuma & Honsiu & 2024 & 1997 \\
\hline 6 & Bandai-san & Honsiu & 1819 & 1888 \\
\hline 7 & Hakkoda & Honsiu & 1585 & 1997 \\
\hline 8 & Tokachi-dake & Hokkaido & 2077 & 1989 \\
\hline 9 & Kirishima-yama & Kiusiu & 1700 & 1992 \\
\hline 10 & Aso-san & Kiusiu & 1592 & 1993 \\
\hline 11 & Unzen & Kiusiu & 1359 & 1990 \\
\hline 12 & On & Kiusiu & 1118 & 1999 \\
\hline 13 & Sakurajima & Kiusiu & 1117 & 2009 \\
\hline 14 & Nakanoshima (Kagoshima) & Riukiu (Tokara) & 979 & 1914 \\
\hline
\end{tabular}

Tab. 1. The highest active volcanoes in Japan (owner compilation on the bases of Bornhof, 2004; Gudowski, Lisowski, 1997; Mydel, R., Groch, J. (eds), 2000) • Najaktywniejsze wulkany Japonii (opracowanie własne na podstawie Bornhof, 2004; Gudowski, Lisowski, 1997; Mydel, R., Groch, J. (eds), 2000) 


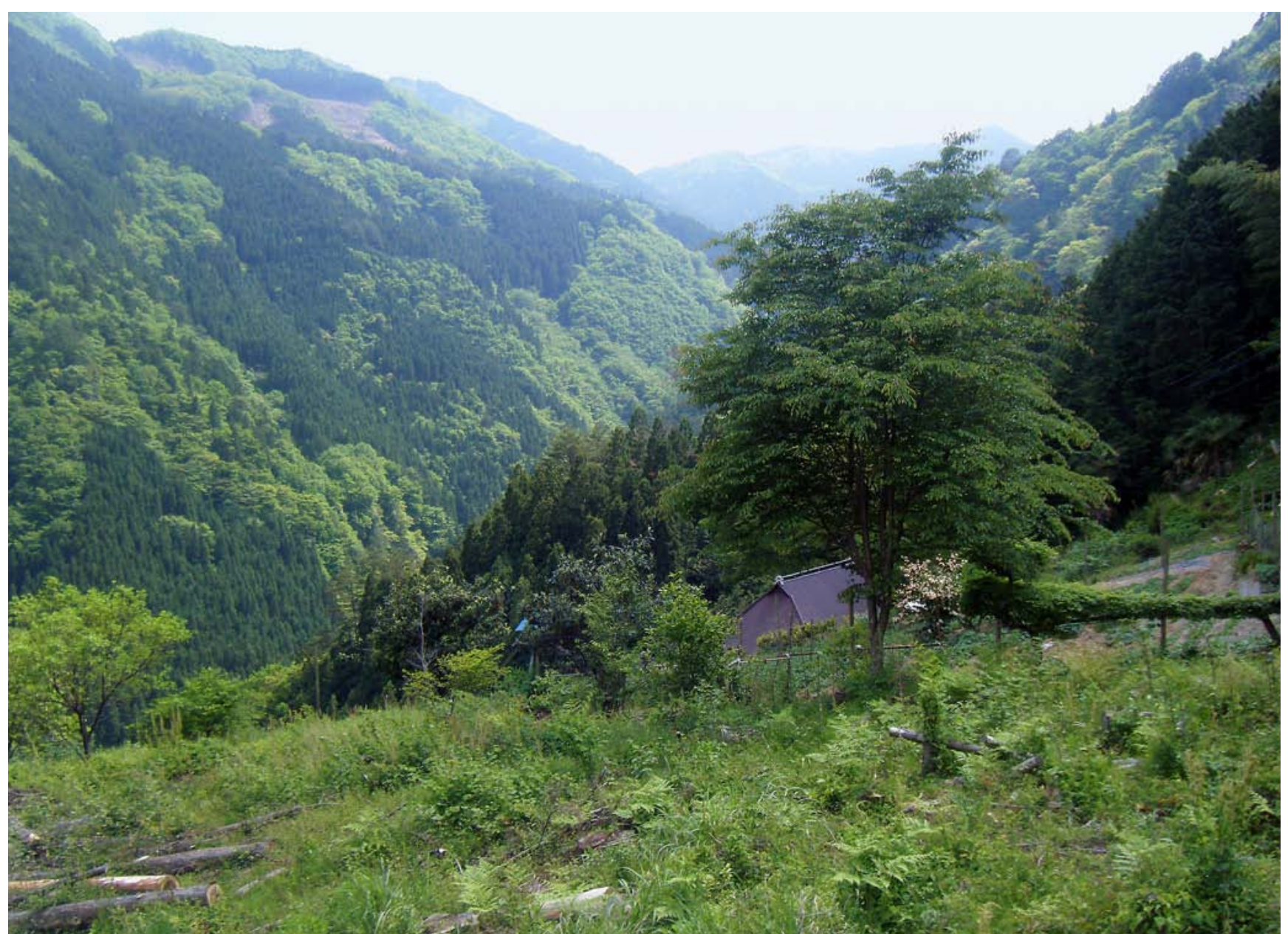

Fig. 5. Mosaics character of landscape - biodiversity - Picturesque forests in Sikoku Mountain - Mt. Tsuguri Quasi National Park, phot. U. Myga-Piątek • Mozaikowata struktura krajobrazu: malownicze lasy na Sikoku (Park Narodowy Gór Tsuguri), fot. U. Myga-Piątek

The example of tourists taking advantage of natural and cultural heritage of hot springs resorts is Kurokawa Onsen (Kyushu Island). As wrote by McMorran, (2008): “The town's success is largely due to its utilization of a nation-wide nostalgia for the country's agricultural past. Through the careful incorporation of elements of the idealized rural village, known as 'furusato' (native place), the resort's business leaders have used the country's rural heritage as a theme in which to situate its own business plan".

Surface features of the Japanese Islands is highly diversified. The main feature of the natural landscape of Japan is its mountainous nature (Fig. 11). Mountains and uplands account for as much as $83.6 \%$ of the area of the country. As many as 580 Japanese peaks are taller than $2000 \mathrm{~m}$ a.s.l., and 21 reach over $3000 \mathrm{~m}$ a.s.l., including the highest mountain of the country - the Fuji-san (3776 m a.s.1.).

Hokkaido is cut through by longitudinal mountain ranges: Kitami in the north, Hidaka in the south-east and Teshio in the west. ly. The central part of the island includes the Ishikari volcanic massif with its highest peak Asahi $(2,291 \mathrm{~m}$ a.s.l.), and a smaller Yūbari range. The Kitakami mountains run longitudinally along the eastern cliff shore in the northern part of Honshu, Tōhoku, and the Ōu mountains run across the central part of the region. These two ranges, being the continuation of mountains on Hokkaido, are separated with the valley of the Kitakami river, flowing into the Pacific Ocean; the southern course of the river flows through Sendai - the main city of the Tōhoku region,. That region was affected with the largest damages during the March earthquake and tsunami. The central part of Honshu, Chūbu, is occupied by extended Mikuni mountains and the Abukuma range near the Pacific shore. To the west are the Japanese Alps, the highest mountains in Japan. They include three main longitudinally-running ranges: Hida in the north, Kiso in the central zone and Akaishi in the south. To the east from the latter range, and to the west from the Izu Peninsula, which juts out into the Pacific Ocean, sits the massif of extinct Fujisan Volcano (3,776 m a.s.l.; Fig. 4).

Most of Shikoku is covered by mountains of the same name, with the tallest peak Ishizuchi (1,981 m a.s.l.; Figs. 5, 6). In the northeastern part of the island, the valley of the Yoshino-gawa river separates the Shikoku Mts. from the small Sanuki range (Figs. 7, 8, 9). The Kyushu mountains with the tallest peak Kujū (1,788 m a.s.l.) also run longitudinally.

The surface features of the Japanese islands determined the distribution of settlements and development of traditional ways of land management. The most clear example of the determining relation between human economy and natural conditions is the terrace system of rice cultivation (Fig. 10). 


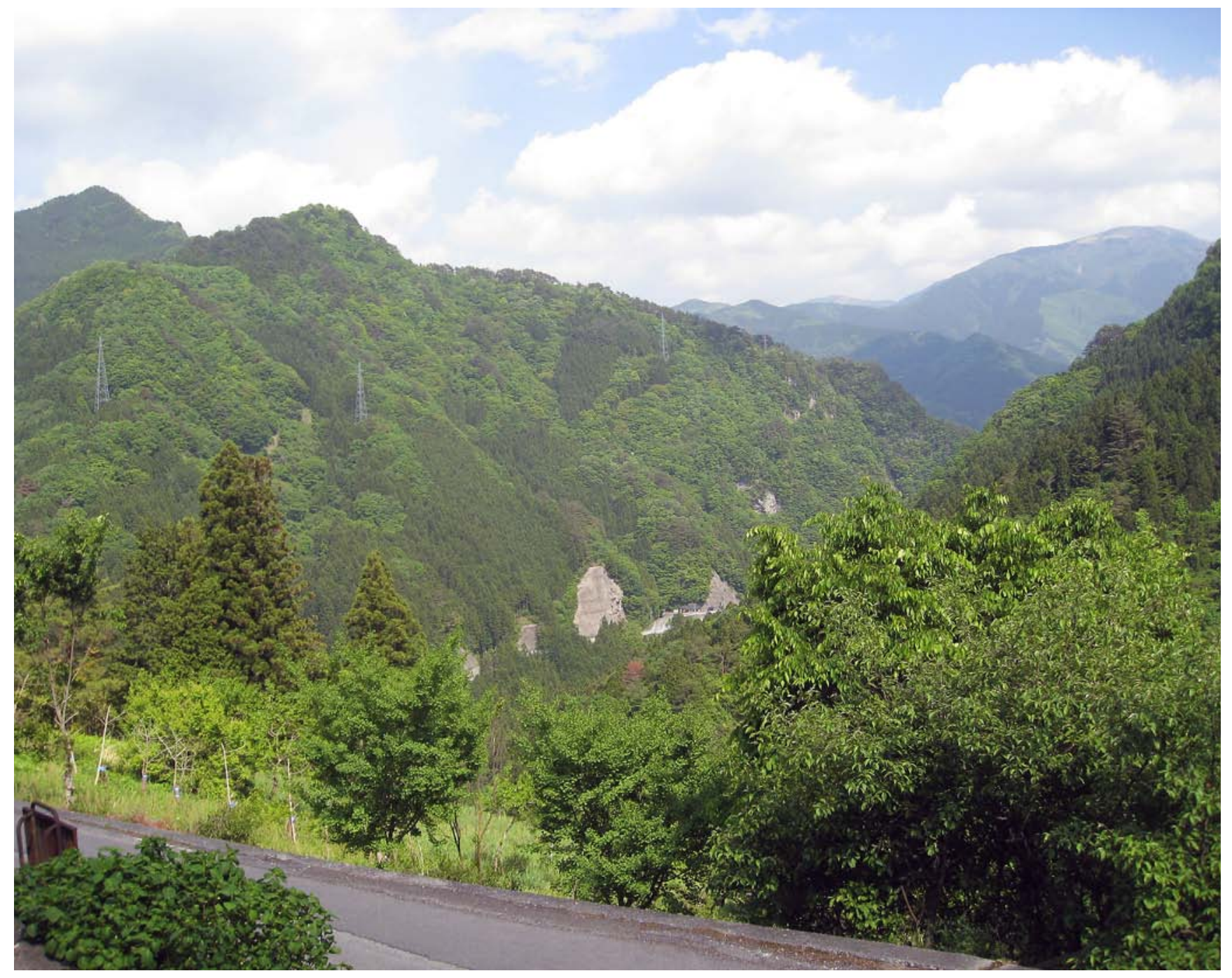

Fig. 6. One of numerous query in Shikoku in Ishizuchi mountain, phot. U. Myga-Piątek • Jeden z licznych kamieniołomów w górach Ishizuchi na Sikoku, fot. U. Myga-Piątek

Fig. 7. River bed rocks in Yoshino river, phot. U. Myga-Piątek • Koryto rzeczne rzeki Joshino, fot. U. Myga-Piątek

Areas of land slope exceeding $20^{\circ}$ account for as much as $28.8 \%$ of the country area. In the southeastern part of Honshu extends the Kantō Plain, comprising the Tokyo agglomeration. The share of typically lowland areas barely reaches $15 \%$ and, alongside fold areas with low denivelation or gentle slopes (thus easy to manage), amounts to slightly over $26 \%$ of the total area (Fig. 11) (Jackowski, 1996). These were areas of the earliest settlement and development of cities. Based on the current distribution of the largest settlement units of Japan, it can be noticed that city agglomerations are located in lowlands: Tokyo-Yokohama-Kawasaki in the Kantō Plain $\left(13,000 \mathrm{~km}^{2}\right)$, Nagoya in the Nobi Plain $\left(1,800 \mathrm{~km}^{2}\right)$, and Osaka-Kioto-Kobe in the Osaka Plain $\left(1,250 \mathrm{~km}^{2}\right)$.

The land relief also determines the layout and features of the hydrographic network. It includes a network of short mountain rivers with numerous steps, waterfalls and rapids. That gives the rivers very natural features (Figs. 12, 13).

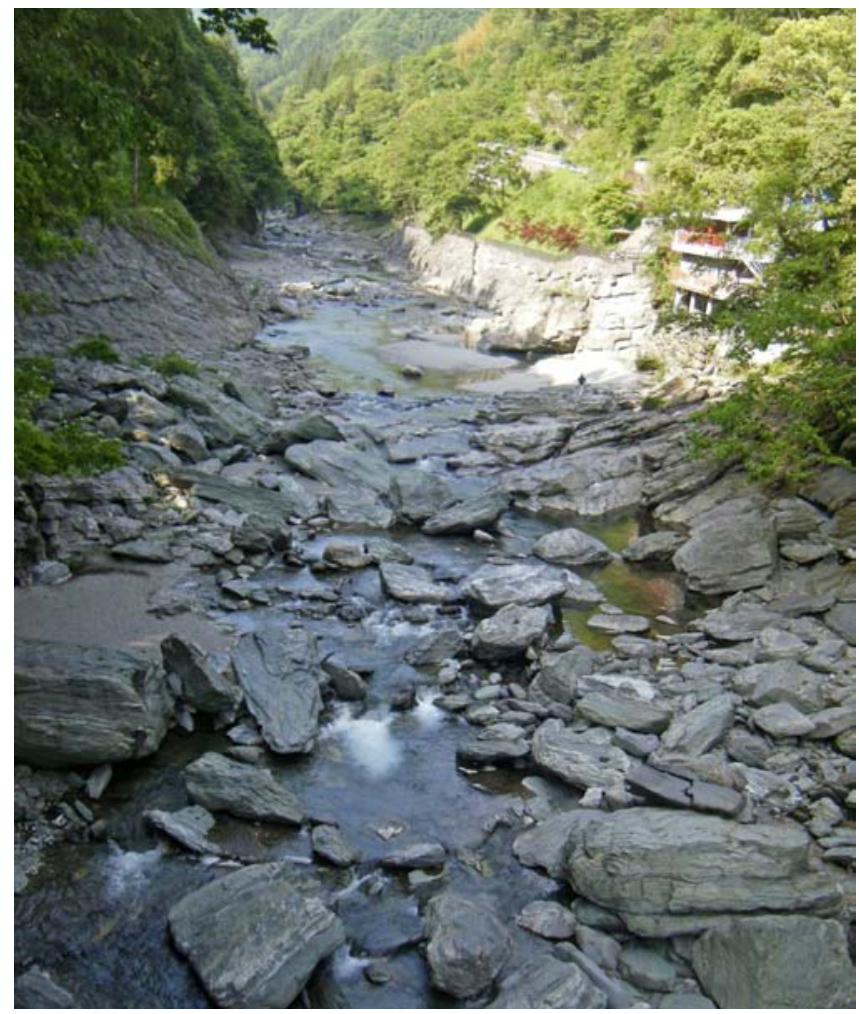




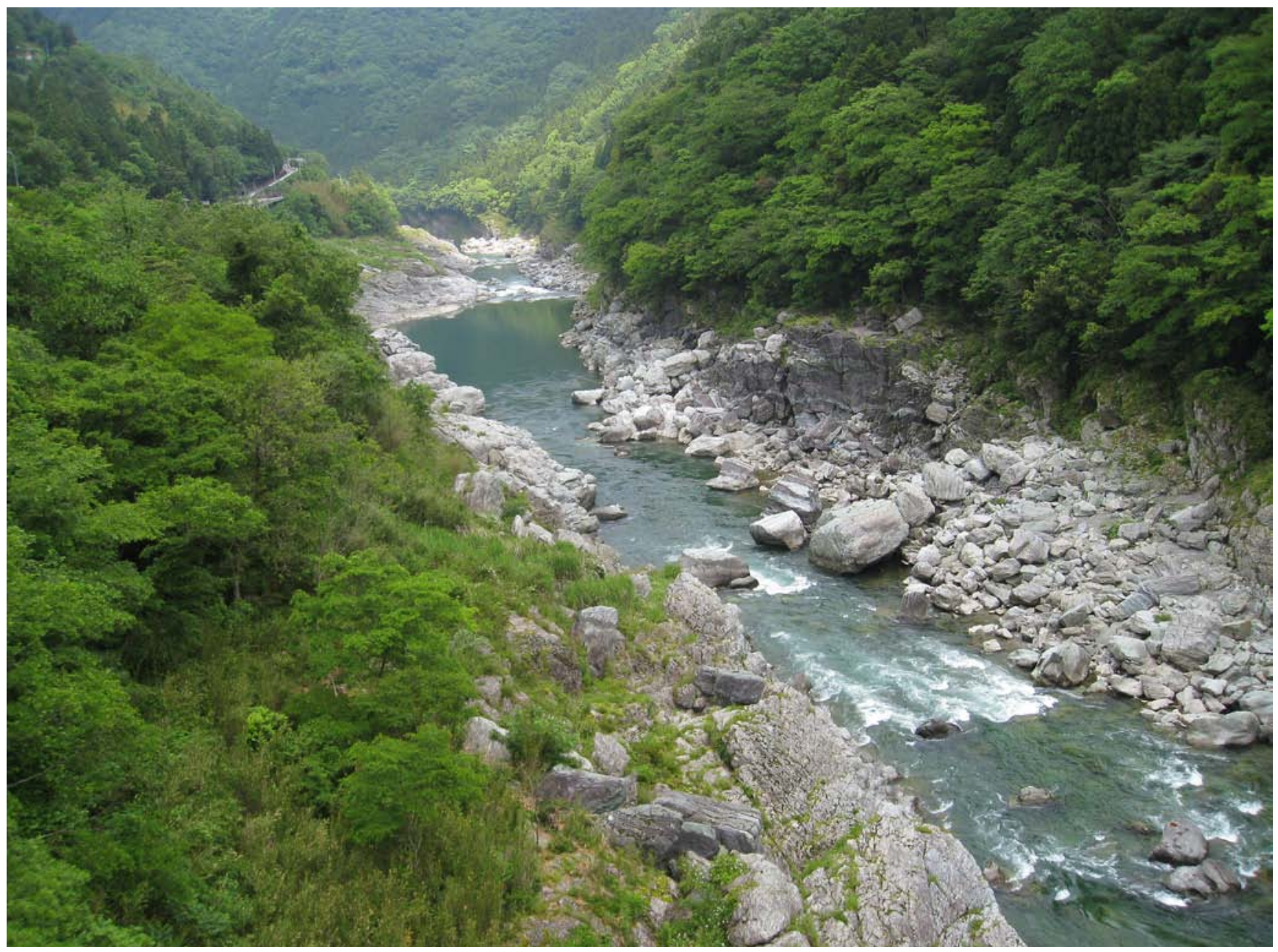

Fig. 8. Transversal profile by Yoshino river (north Shikoku). The Yoshino River has cut trough the Sikoku Mountains over the ages, eroding crystalline schist into winding gorges with myriad shapes and forms, which almost look like marble statues, phot. U. Myga-Piątek • Widok na profil poprzeczny rzeki Yoshino (północne Sikoku). Erozja rzeki Yoshino wytworzyła w łupkach krystalicznych gór Sikoku liczne wąwozy i formy skalne o kształtach zbliżonych do marmurowych posągów, fot. U. Myga-Piątek

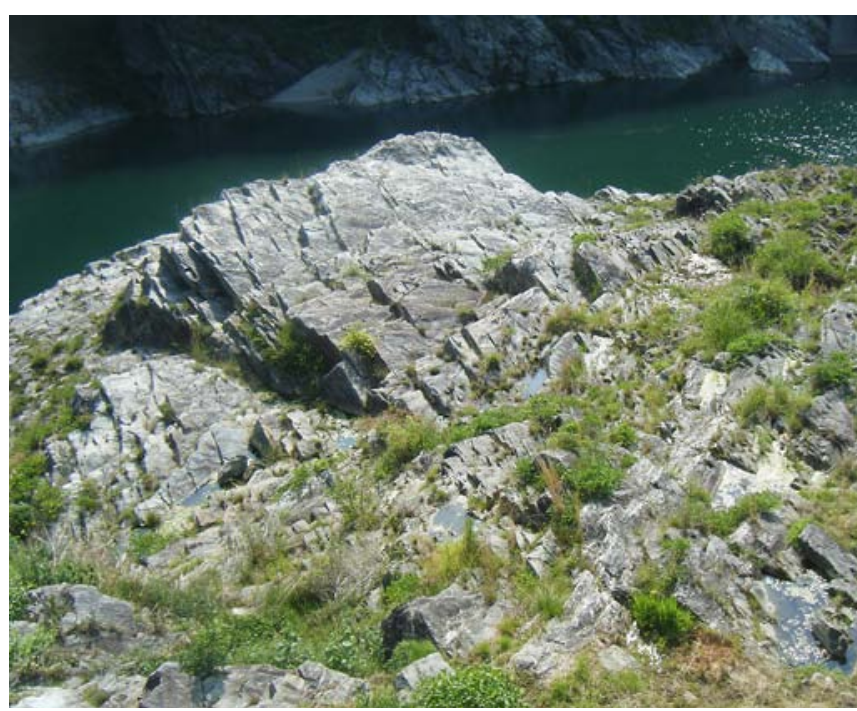

Fig. 9. Examples of crystalline schist, phot. U. Myga-Piątek • Przykłady skał krystalicznych, fot. U. Myga-Piątek
The Japanese islands all belong to the catchment of the Pacific Ocean. Because of large water drops, there is a high hydroenergetic potential and also the waters are used in ploughland irrigation. The longest rivers are: Honshu's Shinano $(367 \mathrm{~km})$ and Tone $(322 \mathrm{~km})$, as well as Hokkaido's longest watercourse Ishikari $(268 \mathrm{~km})$.

There are over 600 lakes in the Japanese islands. The majority of them are located in mountainous regions. Most are tectonic, caldera or crater lakes, or less common, lagoons or artificial lakes. The largest one is the tectonic Lake Biwa in central Honshu, with the area of $670 \mathrm{~km}^{2}$. Lakes larger than $100 \mathrm{~km}^{2}$ in area include east-of-Tokyo Kasumigaura $\left(167.6 \mathrm{~km}^{2}\right)$, Saroma $\left(151.9 \mathrm{~km}^{2}\right)$ in Hokkaido and Inawashiro $\left(103.3 \mathrm{~km}^{2}\right)$ in the Tohoku region. The deepest Lake, Tazawa (423.4 m), is situated in the north of Honsiu. The cryptodepression of Lake Hachirogata ( $4 \mathrm{~m}$ b.s.l.) is situated nearby.

In terms of climatic conditions, the Japanese islands are characterized by high diversity, from the zone of moderate warm climates (Hokkaido, northern Honshu), to subtropical (central and southern Honshu, Shikoku, Kyushu) and tropical climates (the southern edge of Kyushu and Ryukyu). Climatic differences resulting from the latitudinal extension of Japan are magnified by ocean currents flowing along the coasts of the islands. Hokkaido and north-eastern Honshu are surrounded by the cold Oyashio current, whereas the southwestern and western shores by the warm Kuroshio current. The climatic specifications are further strengthened by monsoons. 


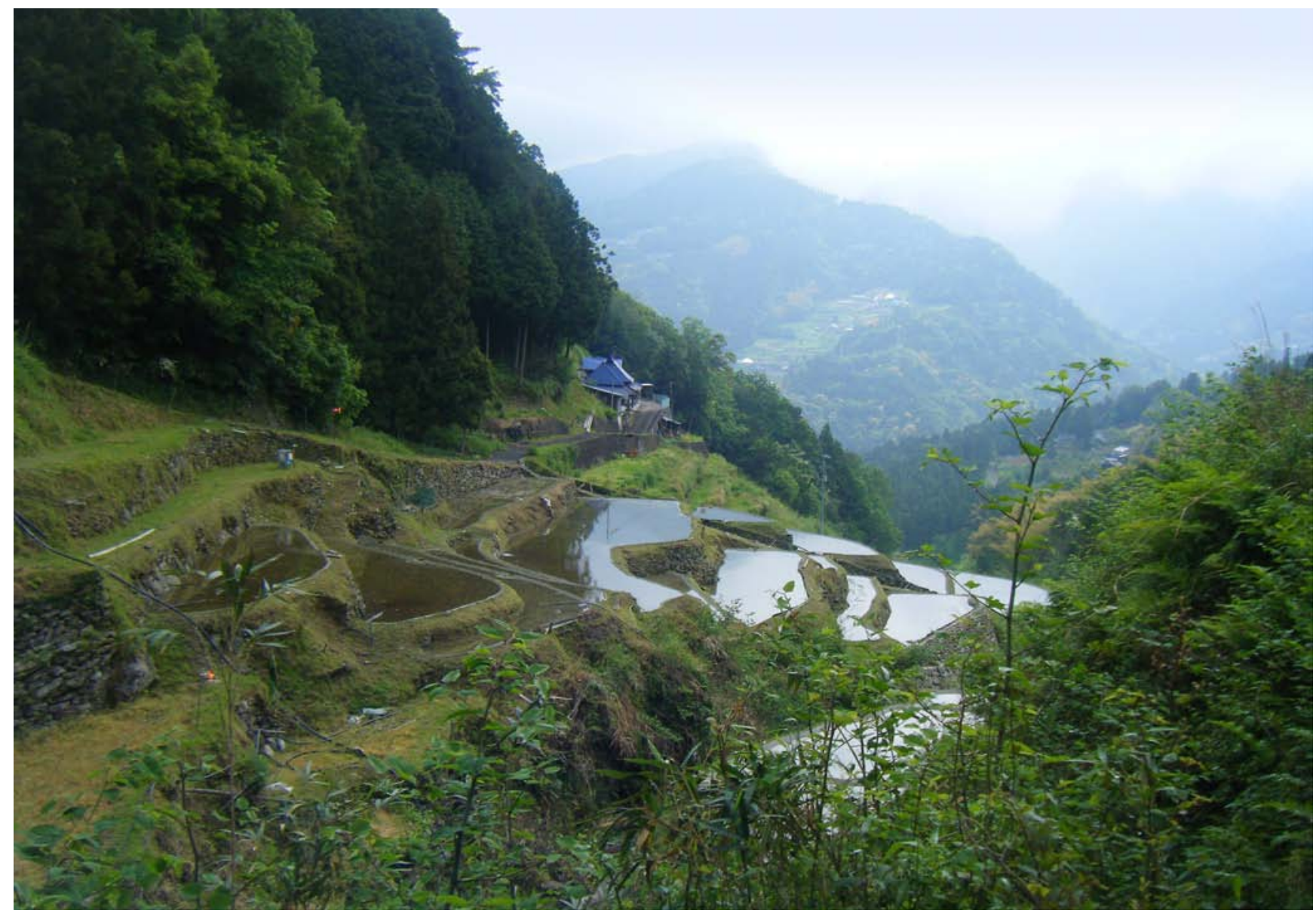

Fig. 10. Traditional form of land using - rice fields „Tanada” - terrace as the way of farming in the mountainous area adapted to suit to their limited landscape, which was passed down from generation to generation. Many photographers come here from all over Japan during the season of rice planting, phot. U. Myga-Piątek • Tradycyjne formy terasowego użytkowania terenu do upraw ryżu. Pola ryżowe „Tanada”. Umiejętności upraw w ograniczonej przestrzeni przekazywane z pokolenia na pokolenia - współcześnie plener fotograficzny w sezonie sadzenia ryżu, fot. U. Myga-Piątek

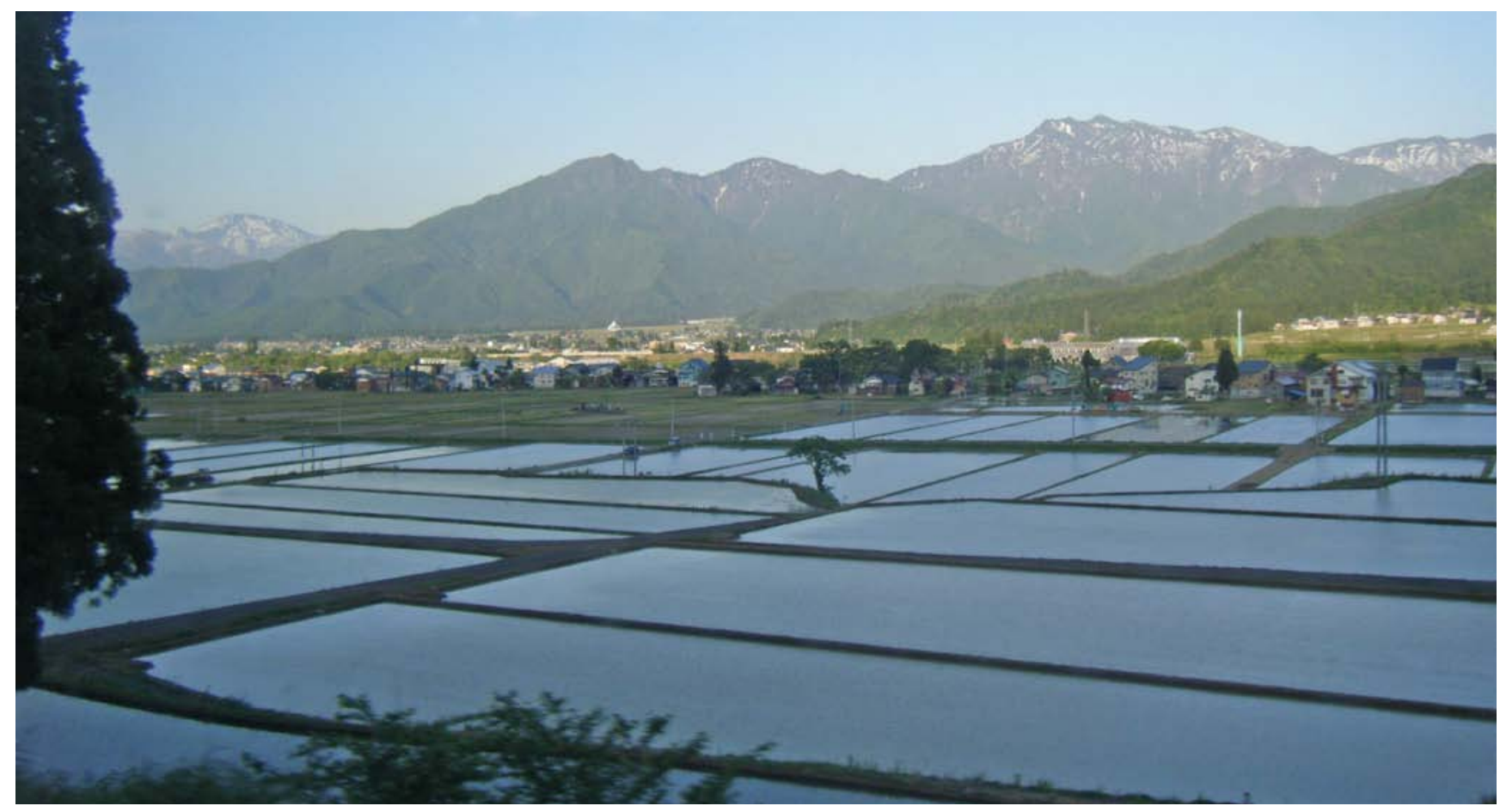

Fig 11. Open landscape in Honshu - valley used for rise fields and settlements, phot. U. Myga-Piątek • Krajobrazy otwarte na Honsiu dolina użytkowana na potrzeby upraw ryżu i skoncentrowanego osadnictwa, fot. U. Myga-Piątek 


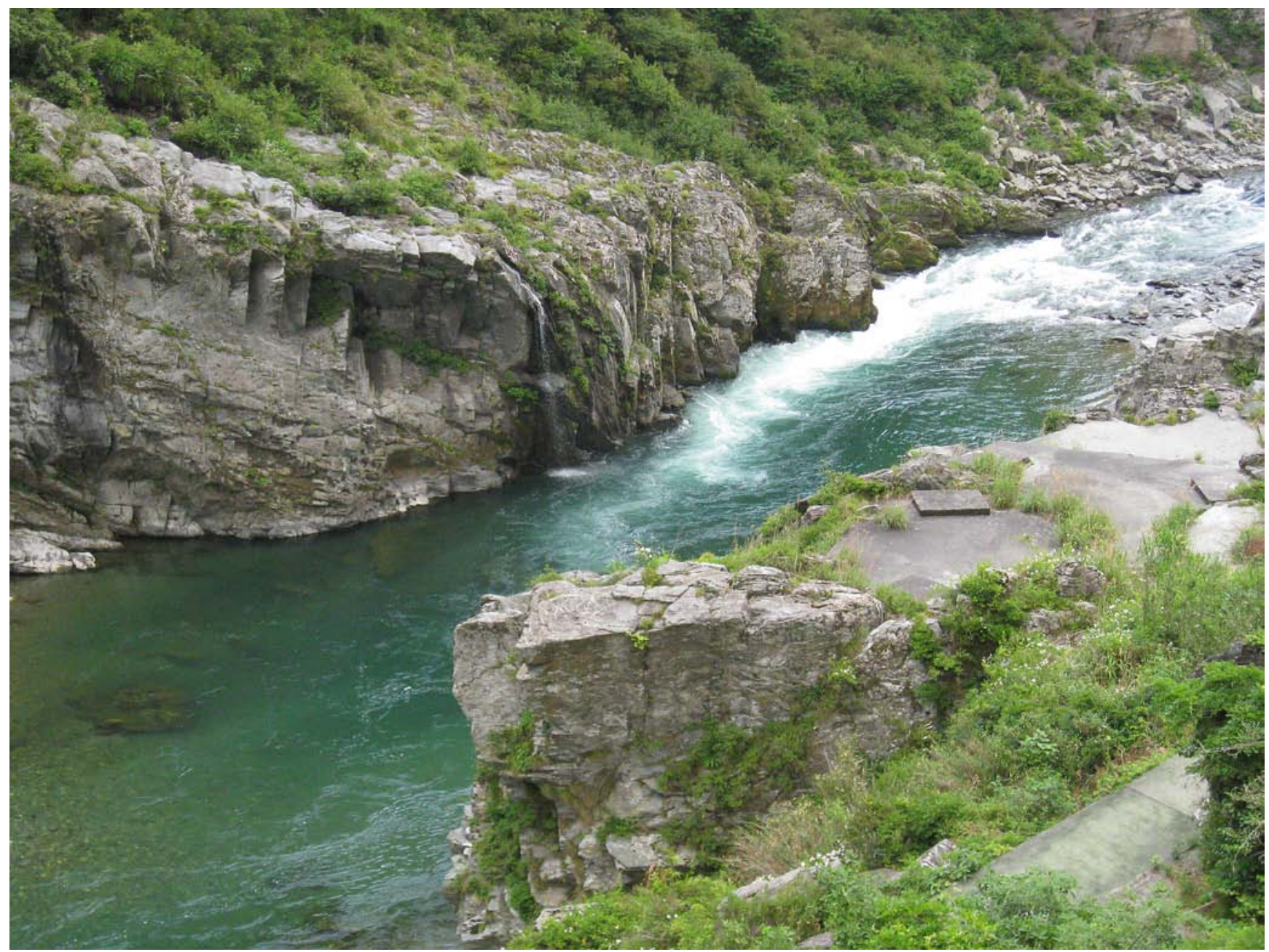

Fig. 12. Oboke-Kaboke Gorge has unusual geological strata, including a rudaceous schist formation and sandstones. Strong current of Yoshinogawa - perfect condition for rafting, phot. U. Myga-Piątek • Wąwóz Kaboke-Oboke ukazujący formacje łupków i piaskowców. Silny prąd rzeki wykorzystywany jest do uprawiania raftingu, fot. U. Myga-Piątek

Forests are a great natural value of Japan; they cover more than $66 \%$ of the country area, which is over twice as much as forest density in Poland. Boreal forests grow in the northern Hokkaido, deciduous forests in the northern Honshu, and evergreen subtropical forests in the south of Honshu, on Shikoku and on Kyushu. The zonal division of vegetation is further complicated by orographic differences (Fig. 5). The altitudinal zonation of plant cover creates the layout of leafy forests which turn into spruce-fir forests, replaced by subalpine brushwood and alpine vegetation in upper sections (Gudowski, Lisowski, 1997; Bornhoff, 2004). Overlapping vertical and horizontal zones over relatively small areas create unique mosaic landscapes, which value is further emphasized by abundant vascular flora (about 5,000 species of vascular plants) mostly composed of relict species from the Tertiary (Jackowski, 1996). Acknowledging the values of the natural environment, the Japanese government included $14 \%$ of the country's territory into the highest form of the protection scheme (national parks, reserves, regional parks). Forest cover determines the unique landscape of Japan foremost among other factors. Coastal forests are protected as national parks: Natohanto Quasi and Echizen Kagakaigan Quasi.

\section{Types of tourism}

that could be developed

based on the values of the abiotic environment

The best conditions for development of geotourism occur in the areas of high geodiversity and a high degree of natural features of the landscape; in pristine, little explored places, where unique rocky forms, geological profiles and exposures have remained. Southeast Asia is placed to geo- and ecotourism (see Weaver, 2002).

Of particular interest are entities with monumental and unique features. The primary function of geotourism is to facilitate theunderstanding the geological history and the present processes, as well as the need to protect the natural environment related to these processes. Geotourism is practiced in selected geological objects, which are, or may become the objects of tourist interest if these are appropriately promoted and accessible (Fig. 13).

The characteristics presented above show that the uniqueness of the landscape of the Japanese islands is mostly determined 
by abiotic and biotic values (McMorran, 2008; Miyakunia, Vander Stoepa, 2006). These might be an attracting factor in tourism development. The strongest points include diversified shoreline, mountainous features of the landscape and active seismic processes.

What makes an unusual value in the development of Japanese tourist flow is a very long $(30,000 \mathrm{~km})$ shoreline. Involvement in tourism, sightseeing and sports in the coastal zone results from diversity and contrasting features of the types of coasts: from cliff coasts in the east and south of the Honshu, to rias coasts around the Sea of Japan, to lagoon and liman coasts with dune ridges in the north of both the Honshu and on Hokkaido, to barrier coral reefs around the Ryukyu islands. Large potential exists for specialized forms of underwater tourism (diving and coral reef exploration).

Lithostratigraphic diversification and tectonic activity of the Japanese islands are foundations for possible development of geological education, sightseeing, mineralogical and exploration tourism, as well as extreme tourism (trips to dormant volcanoes, into zones of tectonic fissures and faults, cliffs, waterfalls, caves or to uninhabited islands). Volcanoes are among the main tourist attractions. The most famous one (Słowakiewicz, Montanaga, 2008) presented in most advertisements and postcards, the Fuji-san (Fig. 4) attracts 400 thousand tourists every year, although the official season of its exploration last only two months, from July 1 to August 31.

Geotourism can also develop thanks to large resources of thermal waters. Over 1,800 health resorts have been set up in sites where springs occur. The largest and best-known resort is Beppu on Kyushu (Bernacka, Piekarska-Gołębiowska, 1996). Thermal waters are commonly used in traditional Japanese baths called onsen (Pawłowska, 2010; Kido, 2006) and guesthouses named ryokan (Włodarczyk, 2006). Hot springs are becoming increasingly popular in various tourist offers; well-known health resorts that use onsens are e.g. Kazurabashi, Iya Olsen, Obokekyo Mannaka, Hikyounoyu, or Sun-River-Oboke. Many health resorts can be visited on the southern coast of Honshu, south of Kanazawa (e.g. Awazu, Yamashiro or Yamanaka). Bioclimatic values of the resorts are further increased by their location near the Echizen-Kagakaigan Quasi National Park.

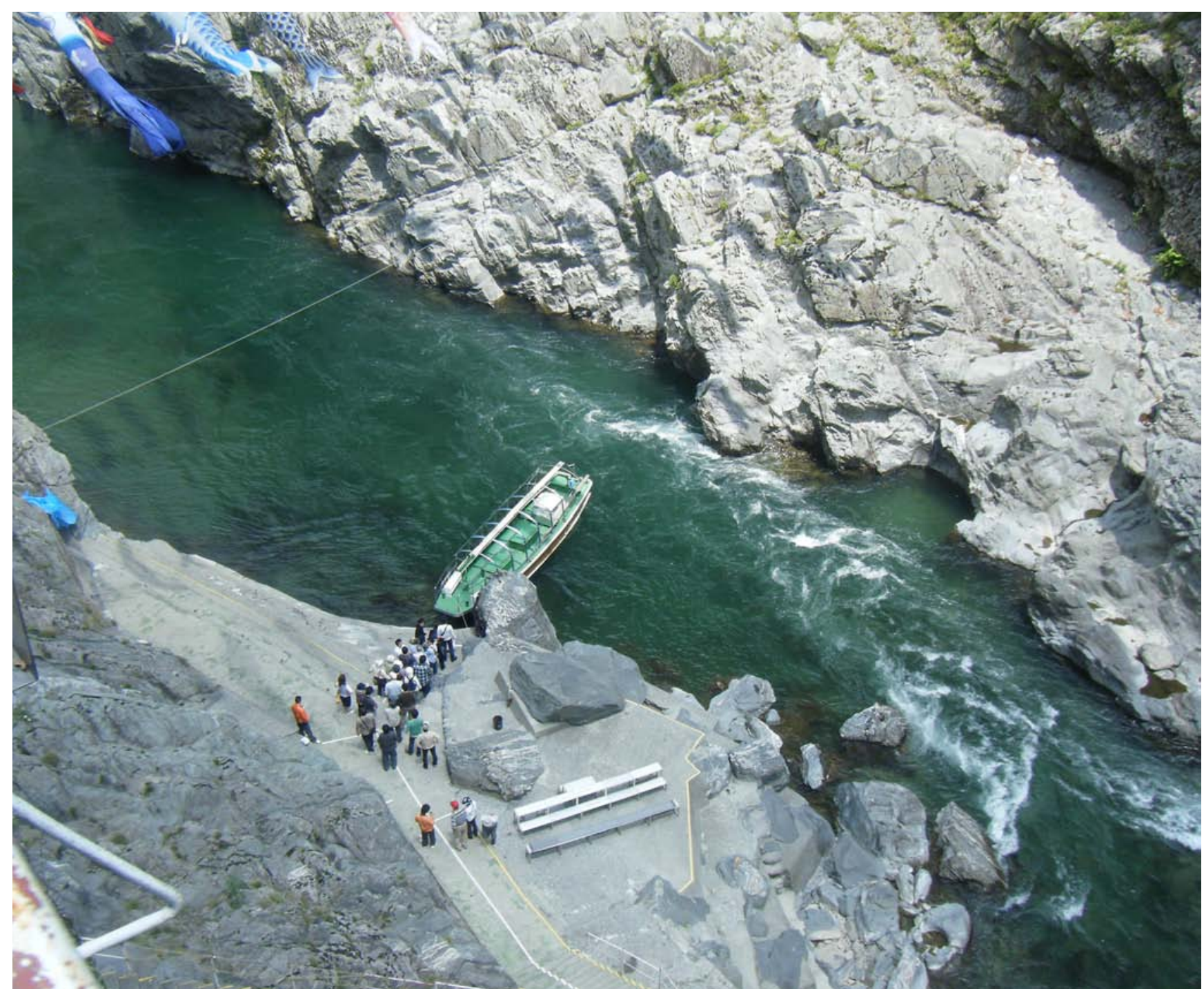

Fig. 13. Tourist boat to rafting down the river - Oboke-Kaboke Gorge has unusual geological strata, including a rudaceous schist formation and sandstones, phot. U. Myga-Piątek • Łódki turystyczne do raftingu po kanionie Kaboke-Oboke, możliwość podziwiania profilu geologicznego w łupkach i piaskowcach, fot. U. Myga-Piątek 


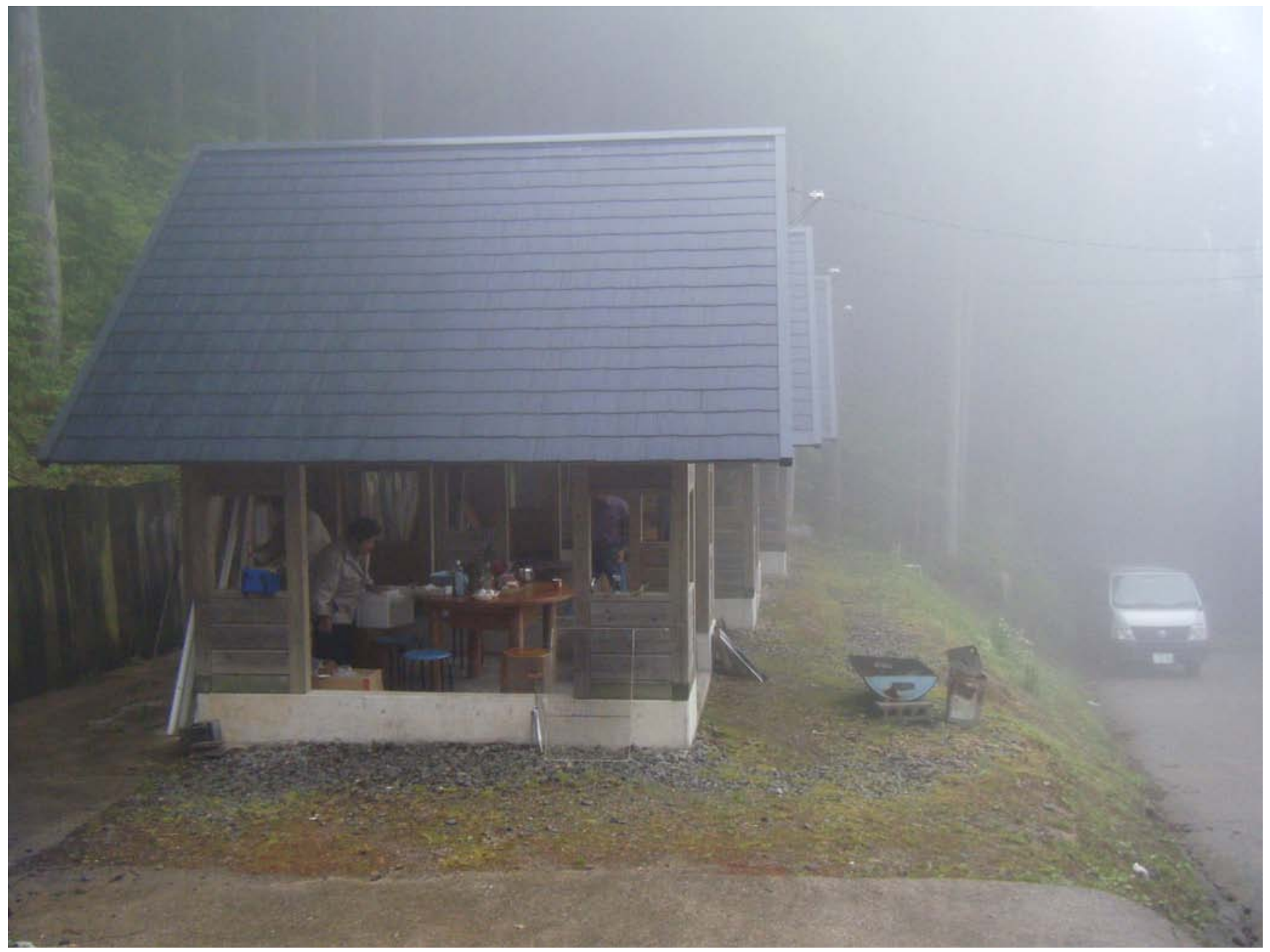

Fig. 14. Tourist station (Finnish-style estate) and ski centre on top Mt. Tsuguri (Sikoku), phot. U. Myga-Piątek - Stacja turystyczna (osada fińskich domków) i centrum narciarskie na szczycie Gór Tsuguri, fot. U. Myga-Piątek

Mountainous features of the landscape of the Japanese islands create extremely favorable conditions for growth of mountain tourism in all its varieties (trekking, hiking, nordic walking, cross-country skiing, Alpine skiing, hang gliding and many others). A skiing station and tourist facilities were built on the top of Mt. Tsuguri in Shikoku (Figs 14, 15). Another skiing center is Kainayama Ski Area within the same national park of the Tsuguri mountains. The mountainous type of landscape can be seen for example on the southern slopes of one of the higher ranges, the Akaishi Sanmyaku, while driving from Kyoto to Tokyo. Unusually impressive is the Hida Sanmyaku range, which tourists cross when travelling by train from Nagano to Kanazawa. The landscapes are available to tourists even from train windows. However, many of these mountain ranges have not been invested in terms of tourism (no walking routes assigned, no inns built).

It should be noted that the mountainous features of the islands and the tectonic activity cause a lot of obstacles in transportation. However, this does not change the fact that technologically advanced Japan has the most modern and best developed railway system in the world. The length of the railway system exceeds $23,000 \mathrm{~km}$ and is still expanding

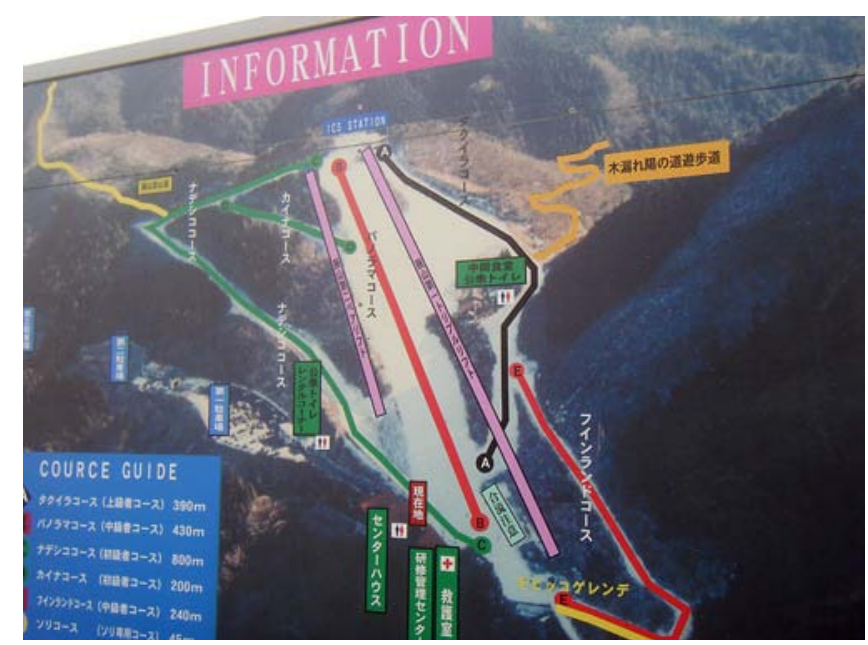

Fig. 15. Tourist information desk in front Mt. Tsuguri (Sikoku), phot. U. Myga-Piątek • Tablica informacyjna w stacji narciarskiej Tsugurii, fot. U. Myga-Piątek

(second to the railway network in the USA, in terms of density). The four largest islands of the archipelago have railway connections where the main carrier is Japan Railway (JR). That is why numerous bridges of various lengths, hung over deeply incised rivers, bays and straits between islands being the common element of the landscape. Vanguard architecture and the scale of these investments often make it possible to treat the journey as a tourist attraction itself. 


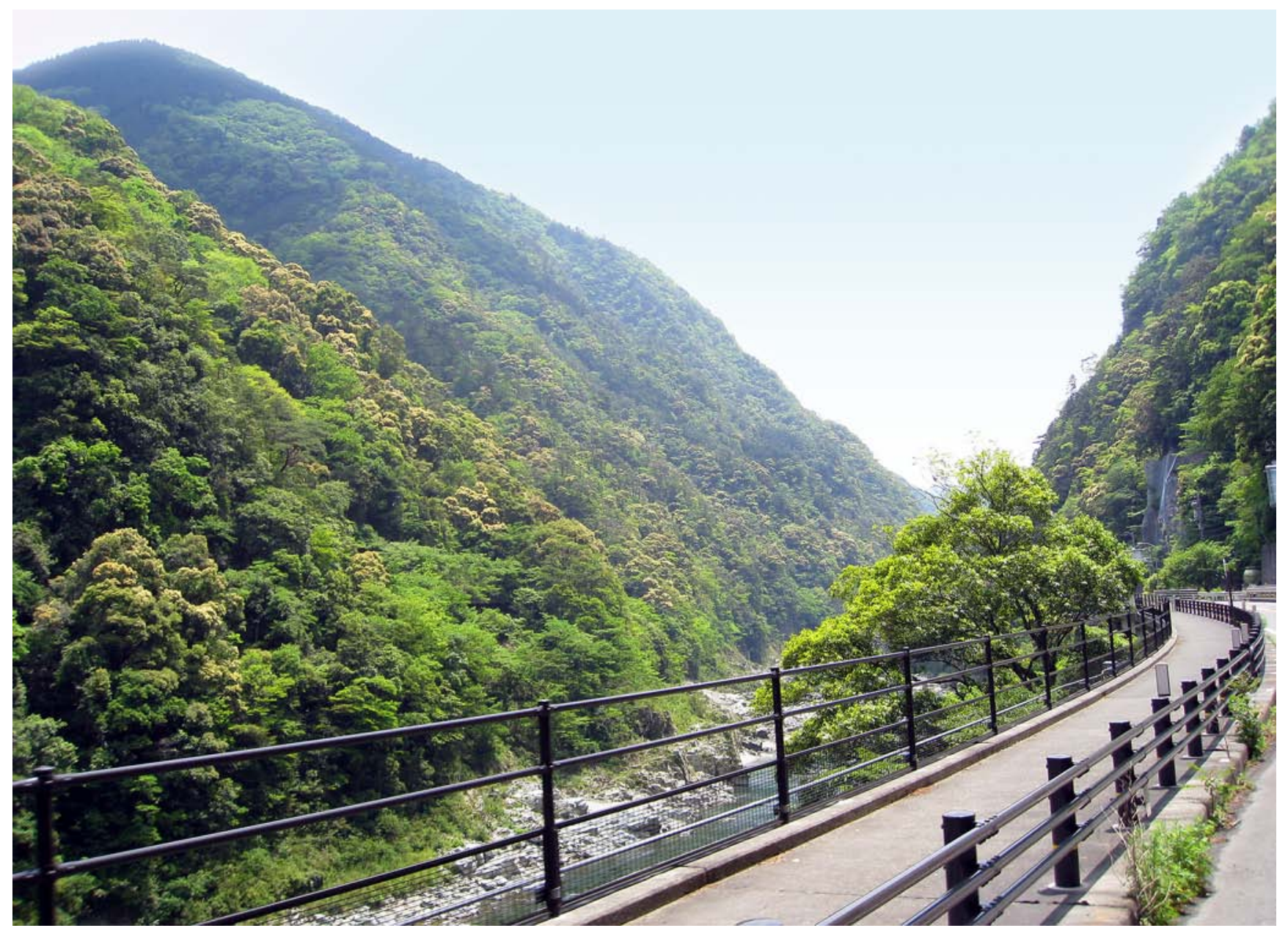

Fig. 16. Tourist scenic route and bridge along the river Yoshinogawa, phot. U. Myga-Piątek • Droga krajobrazowa wzdłuż rzeki Yoshino, fot. U. Myga-Piątek

The geotourist values of the islands can also be observed while white-water rafting. This kind of use of rivers for the needs of tourism was reported in the Ishikawa Prefecture on the rivers Saiga Buchi and Domyo-ga Fuchi near the Yamanaka health resort. The second longest $(194 \mathrm{~km})$ river of Shikoku, the Yoshino-gawa, also presented mountainous features. With numerous gorges, rapids and waterfalls, the Yoshino-gawa provides perfect conditions for rafting, kayaking and canoeing. Particularly attractive is the upper course of the river, known as the Oboke Koboke Gorge, advertised as the greatest tourist attraction of the Shikoku island (Fig. 12). The river is spanned by railroad and road bridges of various types,, as well as by structures designed as sightseeing footbridges, which give an opportunity to admirethe white waters of the Yoshino-gawa (Fig. 16). The most picturesque and widely promoted as a tourist attraction, is the Kazurabashi suspension bridge spanning over the Iya-gawa river (Fig. 17) in the Tokushima Prefecture. A large tourist center with multi-storey car parks is currently under construction nearby.

Waterfalls are also a great attraction. The major Japanese waterfall is 497-meter-high Hannoki in the Toyama Prefecture. Its activity can only be observed between April and July. The second highest, and active all year long, is Shōmyō, where waters fall from $349 \mathrm{~m}$. Other well-known waterfalls of Japan are Nachi (133 m high) in the Wakayama Prefecture and Kegon (96 m high) in the Nikkō.

\section{Summary}

Geotourism development becomes a typical process of all the Far East. Natural environment and cultural landscape of the Japanese islands are very attractive, particularly for tourist from western civilization. Major themes of Japan geo- and ecotourism include spatial concentration at several scales, the presence of geo- and ecotourism that are merged and otherwise linked to other forms of tourism, and the critical influence of external environments (see Weaver, 2002). More and more often Japan focuses on planned tourism development. Discussion is structured around many spheres of tourism linkages. Concepts of physical, cognitive and economic linkages have become widely accepted and applied in many fields, including cognitive planning, architectural design, marketing and psychology. The geotourism management has been implemented in national park design, wildlife protection, community development and transportation systems (Miyakunia, Vander Stoepa, 2006).

Dynamic growth of the tourist sector based on abundant natural values is a matter of forthcoming years. In the case of Japan, there is an important, socio-economic factor that 
stimulates the growth of domestic tourism and recreation: the short but intense rest for the "white collars" (Dziedzic, 1999). Open areas around large agglomerations are already intensively invested in, e.g. the region of Lake Biwa with the surrounding Biwa Quasi National Park provides tourist facilities for residents of agglomerations of Osaka, Kyoto, Nagoya, and others.

While staying in Japan, the author had an occasion to participate in meetings with the representatives of local authorities, societies, local leaders and members of councils, organized in spatial planning institutions and offices. The discussions and analyses of strategic materials show that Japan is increasingly interested in tourism based on natural and scenic values. The projects introduced so far have had little effect and are usually targeted at local residents. The example may be the Miyoshi region, where local authorities have worked out an extensive tourist offer based on diversified, high quality natural values (balneology, educational, specialized adventure tourism, ecotourism, and others).

Various offers are mainly aimed at children and young people. Such programs provide educational purposes and help to popularize the natural (including the geological) heritage of the islands (information from the participant in the project, Kaori Toda, about Japanese school trips to the countryside organized in order to observe the real out-of-town landscape and geological, and ecological values). That kind of promotion of the natural heritage of the islands is extremely important for the young generation, especially in Japan, who should understand the geological processes and phenomena necessary for developing appropriate behavior in the case of earthquakes, volcanic eruptions or tsunami waves. The increasingly important role of geotourism should be based on appropriate planning and management of the environment. It requires considerate, sustainable tourist management combined with promotion and advertising.

On the other hand, globalization and infiltration of social trends from the western world result in the development of new directions in tourism. Apart from opening the domestic market, also residents of other Asian countries, and more and more increasingly from Europe and the USA, show interest in Japan (Myga-Piątek, 2010). The tourist market is often determined by fashion or, as was the case in Japan, a natural disaster.

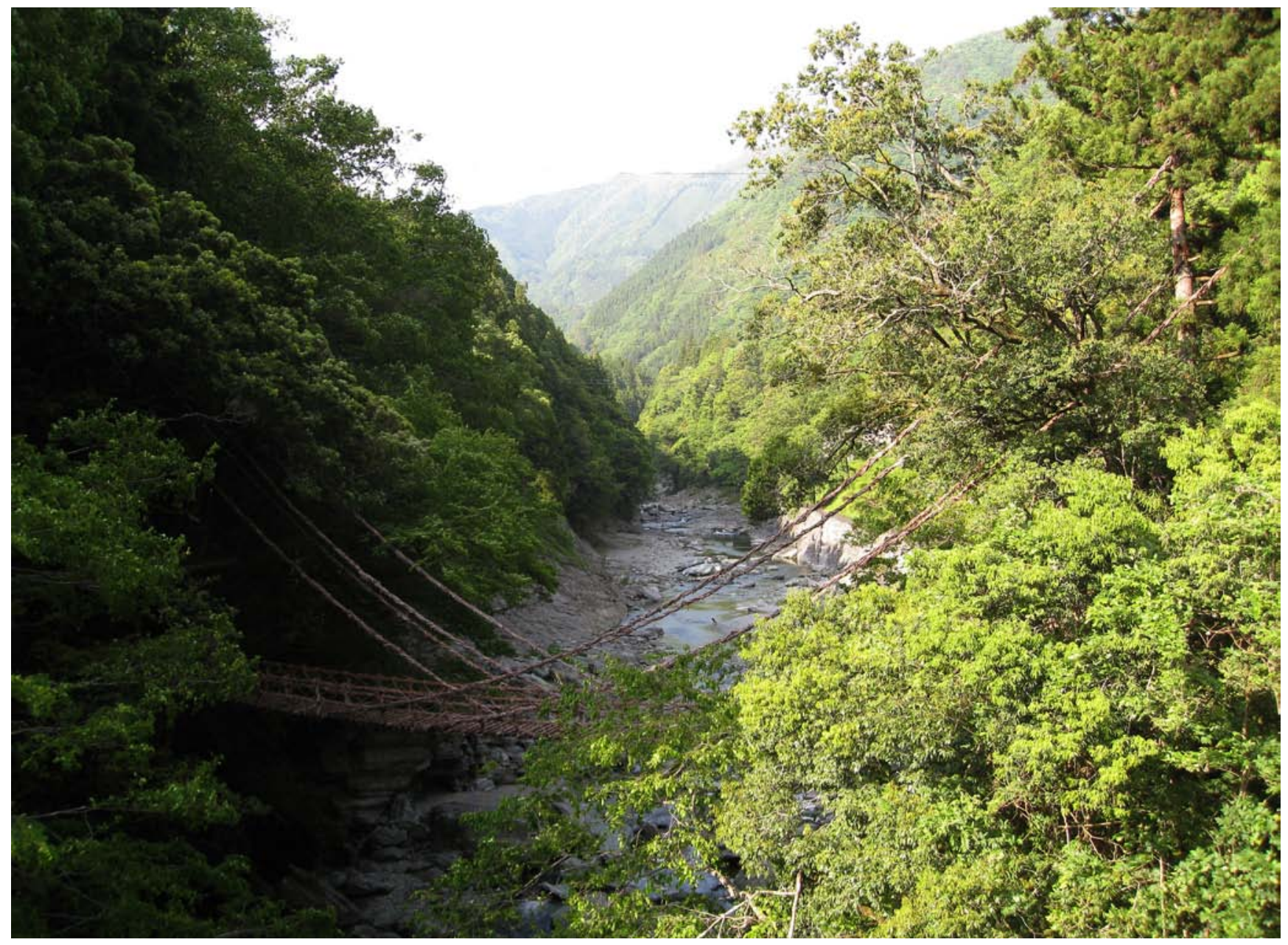

Fig. 17. Kazura Bashi bridge. Famous suspension bridge over the canyon Iya stream. In the west from Tsuguri mountain-prefecture Tokushima, Sikoku). This bridge is made of Actinidia auguta (kind of kiwi vine) and is 45 long, 2 meter wide, and is suspended 15 meters above streams. It was only access over the deep canyon into the mountainous area in those days. The bridge is changed every three years. Designated as a national and prefectural significant folk cultural assets), phot. U. Myga-Piątek • Most Kazura Bashi-słynny wiszący most nad kanionem rzeki Iya, na zachodzie gór Tsuguri, wykonany z pnącza kiwi Actinidia auguta. Most jest odnawiany co trzy lata i jest wliczany do narodowych dóbr kultury, fot. U. Myga-Piątek 
That is why sports like surfing, windsurfing, kitesurfing, winch ball, picigin, hang gliding, yachting, motorboat sports, diving-related tourism (including underwater cave exploration), snorkeling or freediving are becoming more and more popular. Rafting, hydrospeed, kayaking and sport fishing are practiced on mountain rivers, i.e. the Yoshino-gawa, the Oboke, the Koboke, the Iya or the Yamanaka. Mountain ranges which were free from tourist exploration until recently are gradually opening up for various kinds of mountaineering (including bouldering) and cave exploration, as well as trekking, ski-alpinism, alpine skiing and many others.

The extremely "sensitive" geographic environment of the islands is very demanding with regard to adaptation of the areas for sightseeing or exploration. It is not possible to simply implement the experience from e.g. the USA or Europe. That is why Japanese tourist organizations, when making modern advertising offers, draw tourists' attention to cultural values focused rather on large cities than abiotic or ecological values (compare Myga-Piątek, 2010, 2011).

Without thorough research, it is difficult to determine whether such "culture-oriented" tourist offers result from the policy of the Japanese government or rather from a deeper philosophy of the Japanese people and subconscious need to protect the beautiful Japanese environment from commercial mass tourism. Nevertheless, the unique and exotic Japanese culture (largely inspired by the nature) is highly competitive for the environment and, for the time being, is a strong attraction for western tourists. The phase of penetration of unique natural landscapes and geotourist values may follow at a later stages.
It is obvious that the outlined environmental potential of Japan opens practically unlimited opportunities for growth of various forms of geotourism. Large reserves of thermal waters give Japan a chance to become a powerful country in terms of health tourism, especially related to balneology and hydrotherapy, which will possibly be accompanied by a growing number of onsens and, consequently, luxurious spa and wellness centers etc. So far, this offer is mostly used by domestic tourists, but rising fashion for oriental countries may contribute to great opening of Japan to the outside market (mainly wealthy tourists from Europe and the USA). Japanese centers may leave the competitors far behind in that respect. It is also possible to combine health resort functions with congress and business tourism, which already has a large share in the market in Japan.

It should be added that tourist offers of professional European tour operators already include suggestions for visiting the natural values. These include e.g. journey along the route of three most beautiful sights: Amanohashidate, Matsushima, Miyajima; three most famous gardens: Kairaku-en (Mito), Kenroku-en (Kanazawa), Kōrakuen (Okayama); or three best known mountains: Fuji-san, Haku-san, Tate-yama (Myga-Piątek, 2010)

Increased interest in Japan may be expected after the recent earthquake and tsunami which happened in March, 2011. Paradoxically, extreme phenomena, and Japan-related news and comments occurring in worldwide media may contribute to increased tourist flow coming to this country.

\section{Streszczenie}

\section{Uwagi na temat elementów japońskiego krajobrazu i ich atrakcyjności geoturystycznej}

\section{Urszula Myga-Piątek}

Japonia (Fig. 1) nie jest częstym obiektem destynacji turystów z zachodniego kręgu cywilizacyjnego, jeśli nie liczyć podróży biznesowych czy kongresowych. Jest to skutek długoletniej izolacji politycznej Japonii przekładającej się na swoistą izolację turystyczną, a także dużego dystansu - wysokich kosztów podróży i pobytu. Natomiast Japończycy należą do najbardziej aktywnych podróżujących na świecie. W 2007 r. w celach turystycznych wyspy opuściło ponad 17,3 mln Japończyków i liczba ta systematycznie wzrasta (Balaz, 1998; Dziedzic, 1999). Bilans w zakresie liczby uczestników ruchu turystycznego oraz dochodów z usług turystycznych nadal pozostaje w Japonii ujemny (Myga-Piątek, 2010). Obecnie zjawisko to zaczęło się zmieniać, kraj ten otwiera się na przyjezdnych, co jest następstwem panującej mody na Daleki Wschód i Japonię w szczególności, a w związku z tym następuje większe upowszechnianie wiedzy o tym kraju przede wszystkim o charakterze popularnonaukowym. Nadal jednak w oczach turysty z zachodu Japonia postrzegana jest przez pryzmat wielu bardzo wyraźnych symboli (stereotypów), najczęściej dotyczących sfery kulturowej (Myga-Piątek, 2011). Kraj ten dotychczas stawiał na rozwój turystyki kulturowej (miejskiej, wysokiego dziedzictwa kulturowego, kongresowej, biznesowej itp.). Tymczasem jest to kraj wielkiej różnorodności przyrodniczej i co za tym idzie wielkiego potencjału geoturystycznego (Weaver, 2002), co w zestawieniu z krajem wysokiej urbanizacji i zaawansowanych technologii jest szczególnie interesujące. Dziedzictwo geologiczne kraju tworzą reliktowe krajobrazy, które można nadal zaliczyć do qusi-naturalnych.

Celem niniejszego artykułu jest przedstawienie kilku uwag na temat różnorodności krajobrazowej Japonii i na tym tle próba oceny atrakcyjności geoturystycznej tego kraju. Geoturystyka rozumiana jako dział turystyki krajoznawczej w najszerszym znaczeniu zdefiniowana została przez A. Beaver (2005) oraz T. Słomkę i A. Kicińską-Świderską (2004). Artykuł powstał na podstawie obserwacji podczas podróży studyjnej po Japonii w maju 2009 r. odbytej w ramach projektu badawczego pt.: „Studia porównawcze ochrony i użytkowania historycznych miast Kyoto, Kanazawa, Kraków i Warszawa”. Podróż po malowniczych i w dużym stopniu dziewiczych, jak na Japonię, zakątkach 
Sikoku i Honsiu skłoniła autorkę do napisania krótkiego szkicu na temat potencjału geoturystycznego tego kraju.

Najważniejszymi cechami krajobrazu Japonii są duże kontrasty i wielka dynamika środowiska przyrodniczego (Mydel, Groch, 2000).

Wynikają one ze specyficznych cech środowiska geograficznego, do których należą m.in.:

- Wyspiarski charakter kraju (Fig. 1) - Japonia położona jest na 3922 wyspach (Jackowski, 1996), a według innych źródeł aż na 6848 (np. http://pl.wikipedia.org/wiki/Japonia). Wyspy stanowią nawodną część potężnego (3,8 tys. km) łańcucha górskiego, który wznosi się z dna oceanu na wysokość $12000 \mathrm{~m}$. Cztery największe - Honsiu (najgęściej zaludniona), Sikoku, Hokkaido i Kiusiu - stanowią aż 98\% terytorium kraju (Jackowski, 1996; Rutherford, 2006; Gudowski, Lisowski, 1997). Japonia nadal pozostaje w politycznym sporze z Rosją o cztery południowe wyspy archipelagu kurylskiego (Weitz, 2011).

- Prawie 30 tys. km rozmaitych typów wybrzeży: od klifowych na wschodzie i południu Honsiu, przez riasowe wokół wewnętrznego Morza Japońskiego, lagunowe i limanowe często z wałami wydmowymi na północy Honsiu i na Hokkaido do barier raf koralowych wokół wysp Riukiu. To stwarza możliwości adaptacji wybrzeży do celów wypoczynkowych i poznawczych, a także specjalistycznych (hobby, sport, turystyka kwalifikowana np. żeglarstwo, surfing, windserfing, kitesurfing, winch ball, piciging, lotniarstwo, yachting, sporty motorowodne, turystyka nurkowa - w tym w podwodnych jaskiniach, snorkeling, freediving).

- Różnorodne i nadal bardzo aktywne procesy tektoniczne - wyspy japońskie leżą w obrębie aktywnej sejsmicznie strefy górotwórczej, biegnącej wokół Oceanu Spokojnego i ponadto na styku czterech płyt tektonicznych: wielkiej eurazjatyckiej, północnoamerykańskiej, przemieszczającej się w kierunku zachodnim płyty pacyficznej oraz mniejszej płyty filipińskiej. Strefy subdukcji płyt pacyficznej i filipińskiej pod płytą eurazjatycką wyznaczają rowy oceaniczne (Fig. 2), fakty te decydują o bardzo częstych trzęsieniach ziemi, wybuchach wulkanów, zjawiskach tsunami, występowaniu gorących źródeł. Ciągle aktywne procesy wulkaniczne pozostawiają wyraźne ślady we współczesnym krajobrazie (Fig. 3) archipelagu (Uhira et al., 2004; Minakami, 1964; Tsuya, Morimoto, 1963; Geshi et al., 2002). Na terytorium tego kraju znajduje się blisko 260 wulkanów (aktywnych jest od 40 do 80), z czego najwyższym i najsłynniejszym jest Fudżi (Machida, 2002; Koyama, 1998; Ukawa, 2005; Słowakiewicz, Motonaga, 2008). Grupę najaktywniejszych (erupcja w ciągu ostatnich 120 lat) przedstawia tabela 1. Fudżi (Fig. 4) przyciąga rocznie 400 tys. turystów, choć oficjalny sezon na jego zdobywanie trwa tylko dwa miesiące (1 lipca-31 sierpnia).

- Duże różnice hipsometryczne - deniwelacje między szczytami (maks. 3777 m n.p.m.) a dnami dolin (500-200 m n.p.m.) i kryptodepresjami (4 m p.p.m.) - mogą osiągać do $2000 \mathrm{~m}$ (Fig. 6, 9, 10, 11, 12). Główna oś gór i ich układ są wynikiem fałdowań, które miały miejsce w mezozoiku. Odmłodzenie górskiej rzeźby nastąpiło w czasie orogenezy alpejskiej.
W czasie tejże orogenezy powstały liczne spękania oraz zaszły duże przemieszczenia pionowe i poziome. Towarzyszące fałdowaniom ruchy tektoniczne doprowadziły do licznych dyslokacji, wulkanizmu oraz intruzji granitowych i pokryw lawowych oraz tufowych. Fakt ten jest interesujący dla turystyki geologicznej, poszukiwawczej, krajoznawczej.

- Występowanie wielu typów litostratygraficznych skał - od fliszu, przez skały krystaliczne, wulkaniczne i węglanowe (Fig. 3, 8, 9, 12,13). Zróżnicowanie geologiczne i zaangażowanie tektoniczne wysp japońskich otwiera duże możliwości przed geoturytyką - w tym turystyką mineralogiczną, poszukiwawczą, a także ekstremalną typu survival.

- Dobrze rozwinięta sieć rzeczna - gęsta sieć krótkich, wartkich rzek o naturalnym charakterze, z licznymi progami i wodospadami oraz bystrzami, a także ponad 600 jezior (Fig. 7, 8, 12, 13) stwarza wysoki potencjał do raftingu i hydrospeedu, kajakarstwa sportowego, wędkarstwa sportowego; rzeki połączone są licznymi mostami, stanowiącymi także istotny składnik estetyki krajobrazu; wody podziemne związane ze strefą aktywnego wulkanizmu wypływają w około 15 tys. źródłach mineralnych - w większości termalnych (głównie gejzery), na ogólną liczbę 20 tys. źródeł wód o właściwościach leczniczych; koncentracja gejzerów występuje zwłaszcza na Kiusiu i Hokkaido, są one charakterystycznym składnikiem krajobrazu wszystkich wysp japońskich (McMorran, 2008). Wody te były podstawą powstania ponad 1800 uzdrowisk (Bernacka, Piekarska-Gołębiowska, 1996); intensywnie rozwija się turystyka balneologiczna. Największe i najsłynniejsze jest uzdrowisko Beppu na Kiusiu. Wody termalne wykorzystuje się powszechnie w tradycyjnych łaźniach japońskich onsenach i gospodach zwanych ryokan (Pawłowska, 2010; Włodarczyk, 2006).

- Mozaikowość krajobrazu wynikająca z kontrastu litologicznego, morfologicznego, glebowego i roślinnego, co decyduje o dużej malowniczości (Fig. 5). Zapewnia ją także bardzo wysoka lesistość przekraczająca 66\%, piętrowy i strefowy układ roślinności oraz występowanie licznych gatunków endemicznych i reliktowych. $\mathrm{Na}$ północnym Hokkaido rosną lasy borealne, w północnym Honsiu - lasy zrzucające liście na zimę (w składzie dominują buki zwane buna, białe dęby, kasztanowce, klony), na południu Honsiu, w Sikoku i Kiusiu rosną wiecznie zielone lasy podzwrotnikowe z udziałem dębu, czerwonej i czarnej sosny japońskiej, jodły zwyczajnej momi i bambusa). Strefowość roślinności skomplikują dodatkowo różnice orograficzne. Piętrowość szaty roślinnej tworzy układ lasów liściastych przechodzących w lasy iglaste świerkowo-jodłowe, zastępowane powyżej przez zarośla subalpejskie i roślinność alpejską (Bornhoff, 2004). Rząd Japonii, doceniając walory naturalnego środowiska, objął 14\% terytorium najwyższą formą prawnej ochrony - parki narodowe, rezerwaty i parki regionalne (Miyakunia, Vander Stoepa, 2006). Tereny te są przedmiotem eksploracji krajoznawczej, turystyki edukacyjnej i ekologicznej. 
- Górzysty charakter krajobrazu - obszary górskie i wyżynne stanowią aż $83,6 \%$ powierzchni kraju. Aż 580 szczytów Japonii przekracza 2000 m n.p.m (Gołębiowski, 1952), co wpływa to na dynamikę klimatyczną, hydrograficzną, biologiczną (Fig. 11). Stwarza to niezwykle dogodne warunki do rozwoju turystyki górskiej we wszystkich odmianach (Fig. 14, 15, 16, 17) - trekking, hiking, nordic walking, narciarstwo biegowe, zjazdowe, lotniarstwo, wspinaczka alpinistyczna (w tym buldering), turystyka jaskiniowa, a także skialpinizm, turystyka myśliwska, turystyka piesza i krajoznawcza itp.

- Bardzo dynamiczny przebieg zjawisk meteorologicznych (tajfuny, morza mgieł, opady, długo zalegająca w części północnej pokrywa śnieżna, inwersje temperatur); występująca wielka różnorodność klimatyczna - od strefy klimatów umiarkowanych ciepłych na Hokkaido i północnym Honsiu, podzwrotnikowych na środkowym i południowym Honsiu, Sikoku i Kiusiu do zwrotnikowych na południowym skraju Kiusiu i archipelagu Riukiu. Różnice klimatyczne potęgują prądy morskie obmywające wybrzeża wysp oraz monsuny.

Układ rzeźby terenu wysp Japonii zdecydował o rozkładzie osadnictwa i wykształceniu się tradycyjnych sposobów użytkowania terenu (Fig. 10, 11). W południowo-wschodniej części Honsiu rozciąga się równina Kantō, na której położona jest aglomeracja Tokio. Udział obszarów typowo nizinnych sięga zaledwie 15\%, a łącznie z terenami falistymi o niewielkich deniwelacjach lub lekko nachylonych wynosi niewiele ponad $26 \%$ ogólnej powierzchni.

Obecnie strategiczne cele organizacji turystycznych Japonii (w skali makro) kierują uwagę przyjezdnych głównie na walory skupione w obrębie wielkich miast (Dziewanowski, 1975; Myga-Piątek 2010, 2011) i budują ofertę na bazie dziedzictwa kulturowego (McMorran, 2008). Jednak jak wynika z powyższych uwag, Japonia ma ogromny potencjał do rozwoju geoturystyki, gdyż pomimo wysokiej urbanizacji zachowała wysoką bio- i georóżnorodność oraz wysoki stopień naturalności krajobrazu. Obserwacje podczas udziału w projekcie pozwalają przypuszczać, że Japonia w coraz większym stopniu jest zainteresowana rozwojem turystyki bazującej na walorach przyrodniczych i krajobrazowych (Weaver, 2002). Dlatego (na razie w skali lokalnej np. na poziomie prefektur) upowszechniana jest eko- i geoturystyka wykorzystująca regionalne walory przyrodnicze. Potwierdzają to wizyty w biurach planowania przestrzennego i urzędach miejskich, w których przedstawiano projekty prowadzone przez samorządy, stowarzyszenia lub prywatne osoby. Są one skierowane jednak przede wszystkim do japońskiego turysty (Kido, 2003), mają cel - w dużej mierze - edukacyjny, zwrócone są do dzieci i młodzieży i służą upowszechnieniu dziedzictwa przyrodniczego, w tym geologicznego wysp (istotne także z w kontekście kształtowania odpowiednich zachowań na wypadek trzęsień ziemi itp.). Ma to ogromne znaczenie dla młodego pokolenia, które nie tylko w Japonii, lecz także w wielu innych krajach coraz częściej nie zna i nie rozumie wartości geologicznych, przyrodniczych i ekologicznych.

Zatem ogromny potencjał przyrodniczy tego kraju sprawia, że rozwój geoturystyki, także wśród turystów zagranicznych, na szerszą skalę jest kwestią kilku najbliższych lat.

\section{References (Literatura)}

Beaver, A., 2005. A dictionary of travel and tourism terminology (second Edition). International Centre for Tourism Research University of Bournemouth UK and Leisure and Tourist Department Buckinghamshire Chilterns University Collage UK, CABI Publishing.

Balaz, V., 1998. Japanese tourists in transition countries of Central Europe: present behaviour and future trends, Miyuki Mitsutake. Tourism Management, 5: 433-443.

Bernacka, M., Piekarska-Gołębiowska J., 1996. Geografia świata, Londyn.

Dziedzic, T., 1999. Profil japońskiego turysty. Polska Gazeta Turystyczna. 11: $26-28$.

Dziewanowski, K., 1975. Siedem miejsc osobliwych. KAW Prasa-Książka-Ruch. Warszawa.

Geshi, N., Shimano, T., Chiba, T., Nakada, S., 2002. Caldera collapse during the 2000 eruption of Miyakejima Volcano, Japan, Bulletin of Volcanology 64, 1: 55-68

Gołębiowski, J., 1952. Japonia, Warszawa.

Jackowski, A., 1996. Japan. In: J. Warszyńska J. (red.), Encyclopedia of World's Geography part 2, Warszawa.

Japonia. Podróże marzeń 1, 2006. Biblioteka Gazety Wyborczej. Mediaprofit. Warszawa.

Japonia. In: Azja. Encyklopedia geograficzna świata. Tom VI. Kraków, PPWK \& OPRES, 1997.

Japonia. Przewodnik National Geographic, 2004.

Kido, E.M., 2003. Japońskie korporacje i ich pracownicy - stereotyp i rzeczywistość (cz. II). Gazeta Klubu Polskiego w Japonii 3 (30).
Koyama, M., 1998. Reevaluation of the eruptive history of Fuji volcano, Japan, mainly based on historical documents (in Japanese with English abstract). Bulletin Volcanological Society of Japan, 43: 323-348.

Machida, H., 2002. Volcanoes and tephras of in the Japan area. Global Environmental Research, 6: 19-28.

Minakami, T., 1964. The 1962 Eruption of Miyake-sima, one of the Seven Izu Islands, Japan. Bulletin of Volcanology, 27, 1: 25-235.

Miyakunia, K., Vander Stoepa, G.A., 2006. Linking Linkage Concepts from Diverse Fields to Build a Community-Based Tourism Planning Framework: The Case of Shuri, Japan. Tourism Geographies 8, 3: 286-309.

McMorran, Ch., 2008. Understanding the 'Heritage' in Heritage Tourism: Ideological Tool or Economic Tool for a Japanese Hot Springs Resort? Tourism Geographies, 10, 3: 334-354.

Mydel, R., Groch, J. (red.), 2000. Przeglądowy atlas świata. Azja. cz. 1. Fogra Oficyna Wydawnicza, Kraków.

Myga-Piątek, U., 2010. Uwagi o przyrodniczych aspektach atrakcyjności turystycznej Japonii. Konfrontacja stereotypów z doświadczeniami z podróży. Czasopismo Techniczne, 107, 12: 253-273.

Myga-Piątek, U., 2011. Sacrum w krajobrazie Japonii. Peregrinus Cracoviensis, 22: 267-287.

Pawłowska, K., 2010. Krajobraz - architektura - ludzie. Japońsko-polskie studia porównawcze. Czasopismo Techniczne, 107, 12: 7-53.

Słomka, T., Kicińska-Świderska, A., 2004. Geoturystyka - podstawowe pojęcia. Geoturystyka, 1: 5-8. 
Słowakiewicz, M., Motonaga, R., 2008. Fudżi - święta góra Japonii. Przeglad Geologiczny, 10: 881-884.

Tsuya H., Morimoto, R., 1963. Types of volcanic eruptions in Japan. Bulletin of Volcanology 26: 209-222.

Uhira, K., Baba, T., Mori, H., Katayama, H., Hamada, N., 2004. Earthquake swarms preceding the 2000 eruption of Miyakejima volcano, Japan. Bulletin of Volcanology 67, 3: 219-230.

Ukawa, M., 2005. Deep low-frequency earthquake swarm in the mid crust beneath Mount Fuji (Japan) in 2000 and 2001. Bulletin of Volcanology, 68: $47-56$
Weitz, R., 2011. Dlaczego Rosja rzuca wyzwanie Japonii w kwestii Kuryli. World Politics Review http://www.worldpoliticsreview.com/article. aspx?id=5181 (data pobrania 06.03.2011)

Weaver, D., 2002. Asian ecotourism: Patterns and themes Tourism Geographies 4, 2: 53-172.

Włodarczyk, B., 2006. Hotele Ryokan - kwintesencja tradycyjnej Japonii. Turystyka i Hotelarstwo, 9: 35-55.

\section{Websites:}

$\mathrm{http} / / /$ wiadomosci.gazeta.pl/Wiadomosci/ as of 5.04.2011

http://en.wikipedia.org/wiki/Japan 